\title{
Metabolic reprogramming of T regulatory cells in the hypoxic tumor microenvironment
}

\author{
Varun Sasidharan Nair ${ }^{1} \cdot$ Reem Saleh $^{1} \cdot$ Salman M. Toor ${ }^{1} \cdot$ Farhan S. Cyprian $^{2} \cdot$ Eyad Elkord $^{3}$ (D)
}

Received: 30 September 2020 / Accepted: 21 December 2020 / Published online: 3 February 2021

(c) The Author(s) 2021, corrected publication 2021

\begin{abstract}
Metabolic dysregulation in the hypoxic tumor microenvironment (TME) is considered as a hallmark of solid tumors, leading to changes in biosynthetic pathways favoring onset, survival and proliferation of malignant cells. Within the TME, hypoxic milieu favors metabolic reprogramming of tumor cells, which subsequently affects biological properties of tumor-infiltrating immune cells. T regulatory cells (Tregs), including both circulating and tissue-resident cells, are particularly susceptible to hypoxic metabolic signaling that can reprogram their biological and physicochemical properties. Furthermore, metabolic reprogramming modifies Tregs to utilize alternative substrates and undergo a plethora of metabolic events to meet their energy demands. Major impact of this metabolic reprogramming can result in differentiation, survival, excessive secretion of immunosuppressive cytokines and proliferation of Tregs within the TME, which in turn dampen anti-tumor immune responses. Studies on fine-tuning of Treg metabolism are challenging due to heterogenicity of tissue-resident Tregs and their dynamic functions. In this review, we highlight tumor intrinsic and extrinsic factors, which can influence Treg metabolism in the hypoxic TME. Moreover, we focus on metabolic reprogramming of Tregs that could unveil potential regulatory networks favoring tumorigenesis/progression, and provide novel insights, including inhibitors against acetyl-coA carboxylase 1 and transforming growth factor beta into targeting Treg metabolism for therapeutic benefits.
\end{abstract}

Keywords T regulatory cells $\cdot$ Hypoxia $\cdot$ Tumor microenvironment $\cdot$ Metabolism $\cdot$ Glycolysis $\cdot$ Fatty acid metabolism

\section{Introduction}

Cancers are polygenic diseases initiated by multiple oncogenic factors that dysregulate the expression of tumor suppressor genes and/or proto-oncogenes leading to malignant progression [1]. The neoplastic tissue is comprised of heterogeneous population of tumor cells, in a milieu of immune (e.g., myeloid cells, lymphocytes, and naturalkiller cells), and non-immune cells (e.g., fibroblasts and endothelial cells) embedded in the extracellular matrix

Eyad Elkord

e.elkord@salford.ac.uk

1 Cancer Research Center, Qatar Biomedical Research Institute (QBRI), Hamad Bin Khalifa University (HBKU), Qatar Foundation (QF), Doha, Qatar

2 Department of Basic Medical Sciences, College of Medicine, Member of QU Health, Qatar University, Doha, Qatar

3 Biomedical Research Center, School of Science, Engineering and Environment, University of Salford, Manchester M5 4WT, UK with a plethora of cytokines and chemokines, known as tumor microenvironment (TME) [2-4]. TME has dynamic attributes with pro- and anti-tumorigenic properties, which can also influence drug responses [5]. Tumor cells evade host-immunosurveillance by recruiting surplus of immunosuppressive cells including $\mathrm{T}$ regulatory cells (Tregs) $[6,7]$ and myeloid-derived suppressive cells (MDSCs) [6], which suppress the proliferation of cytotoxic $\mathrm{T}$ cells (CTLs) and favor malignant progression [8]. Amongst these suppressive cells, Tregs are considered as the masterregulatory cells, which not only secrete cytokines that promote onset and proliferation of malignancies, but also play indispensable roles in the induction of neo-angiogenesis and metastasis [9-12]. Accumulating evidence suggest that Treg infiltration was evident in vast majority of solid tumors including breast [7], colon [6], pancreatic [13] and ovarian cancer [9]. Tumors samples from advanced stages of cancer exhibit higher infiltration of Tregs, compared with samples obtained from early stages of cancer [14]. Moreover, meta-data analyses showed that higher Treg infiltration is negatively correlated with cytotoxic $\mathrm{CD} 8^{+}$ 
$\mathrm{T}$ cell infiltration and that is associated with poor-disease prognosis [15]. Currently, it is believed that Treg infiltration favors tumor progression and dampens anti-tumor immune responses; thus, it is essential to understand the progression and functions of Tregs in the TME $[16,17]$.

Tumor cells adapt to multiple metabolic processes including glycolysis, oxidative phosphorylation (OXPHOS) and fatty acid metabolism to obtain energy for their survival and progression in adverse tumor milieu [18]. Moreover, the differentiation of T cells within the TME is indirectly regulated by tumor-mediated metabolites and favors tumor progression [19]. Within the TME, metabolic reprogramming of $\mathrm{T}$ cells is initiated by the activation of $\mathrm{T}$ cell receptor (TCR) signaling along with various costimulatory molecules, resulting in the production of sufficient ATP to meet energy requirements for T cell proliferation and effector functions [20]. Interestingly, T cells isolated from the TME frequently exhibit exhaustive $\mathrm{T}$ cell markers and possess distinct metabolic signatures including reduction in the uptake of glucose and upregulation of reactive oxygen species (ROS) [21]. These metabolic defects could be circumvented and partially restored the activation of tumor-infiltrating $\mathrm{CD} 8^{+} \mathrm{T}$ cells (TILs) through the adequate supplementation of pyruvate and neutralization of ROS [21]. These reports suggest that tumor metabolic environment could alter the regulation, function and tumor-antigen recognition of $\mathrm{T}$ cells, leading to inadequate anti-tumor responses.

It has been reported that accumulation of lactate and carbon dioxide could efficiently reprogram the metabolic potentials of tumor cells, including elevated nutrient uptake and glucose metabolism and favor the differentiation of Tregs by inhibiting the infiltration of effector $\mathrm{T}$ cells within the TME [22, 23]. Moreover, hypoxic conditions as a result of increased tumor growth and oxygen deprivation stabilize the expression of hypoxia-inducible factor 1- $\alpha$ (HIF1- $\alpha$ ), which in turn mediates the induction of FoxP3 expression and favors Treg stability [24, 25]. Therefore, comprehensive analyses of malignancy-induced metabolic/hypoxic regulation of T cells can improve current immunotherapeutic modalities. Numerous studies have focused on the metabolic reprogramming of tumor cells and their influence over $\mathrm{T}$ cell function within the TME; however, limited data are available on the metabolic-induced alterations in Tregs in the TME. This review highlights the metabolic reprogramming of physicochemical characteristics of Tregs, their function, differentiation and crosstalk within the TME. Additionally, we focus on the potential metabolic pathways of Tregs within the TME, which may be targeted for improvement of prognosis and development of novel therapeutic strategies.

\section{Metabolism in the tumor microenvironment}

Tumor cells are characterized by their competence to adapt with altering environmental cues by exploiting various nutrients to uphold their necessitating anabolic requirements [3]. This sustained energy demand is accomplished by adequate supply of nutrients and oxygen via tumor vasculature [26]. Consequently, these extracellular nutrients are indispensable for cancer cells to meet their high-energy demand during rapid, uncontrolled proliferation [26]. Unlike normal cells, malignant cells have higher metabolic plasticity, which could reshape the environment even in nutrient-deprived conditions per se [27]. This plasticity has profound influence on tumor differentiation and gene expression within the TME [27]. In this context, Pavlova and colleagues classified tumor-associated metabolic modifications into six groups: (1) deregulation in glucose and amino acid metabolism, (2) altered nutrient uptake, (3) utilization of intermediates from citric acid cycle (TCA cycle)/glycolysis for the biosynthesis of nicotinamide adenine dinucleotide phosphate (NADPH), (4) increased nitrogen requirement, (5) variations in the regulation of metabolite-dependent gene expression and (6) interactions between metabolic pathways within the TME [27].

It has been reported that the highly proliferating cancer cells modify the metabolic components of the TME. For instance, malignant cells take up higher amount of glucose leading to the biosynthesis of large amount of lactate, which could influence many cell populations within the TME [28]. Higher accumulation of lactate creates an immune-subversive milieu by reducing dendritic and $\mathrm{T}$ cell activation and migration of tumor-associated macrophages/monocytes [28, 29]. Moreover, the excess accumulation of lactate polarizes resident macrophages to highly activated/ immunosuppressive M2 state and promotes angiogenesis [30, 31]. Excess levels of lactate also favor the biosynthesis of hyaluronic acid by fibroblasts, contributing to higher tumor invasiveness [32].

Hypoxia-inducible factor 1-alpha (HIF-1 $\alpha$ ) is the key transcriptional factor of hypoxic cells, a hallmark of the TME, and is a downstream target of glucose transporter- 1 (GLUT-1) [33]. During hypoxic conditions, the higher glucose uptake by cancer cells could upregulate the stability of HIF-1 $\alpha$, which in turn leads to the attenuation of anti-tumor immune responses [34]. In HIF- $1 \alpha$-knockedout murine models, the anti-tumor immune responses of $\mathrm{CD}^{+}{ }^{+}$TILs improve through the activation of peroxisomeactivated receptor $\alpha$ (PPAR $\alpha)$ signaling and also elevated metabolism of fatty acids [35]. HIF- $1 \alpha$ promotes the migration of Tregs in the TME through the upregulation of glycolysis and fatty acid oxidation (FAO) within the TME [36]. Indeed, HIF-1 $\alpha$-deficient Tregs exhibit reduction in 
glycolytic-driven Treg migration and oxidation of fatty acid-driven immunosuppression, which in turn upregulates anti-tumor immune responses of $\mathrm{CD} 8^{+}$TILs [36].

Glucose metabolism is the key energy source of $\mathrm{T}$ cells for their polarization toward tumor antigen-specific effector $\mathrm{T}$ cells. Within the TME, the scarcity of glucose for T cells affects their differentiation to effector T cells. Moreover, a low-glucose milieu could diminish glycolysis of T cells by decreasing serine/threonine-protein kinase (AKT) signaling and inducing the apoptosis of TILs through the upregulation of pro-apoptotic proteins [20]. This metabolic microenvironment may also promote the polarization of naïve $\mathrm{CD} 4^{+}$TILs to peripherally induced Tregs [37]. The stimulation of Treg differentiation and their suppressive characteristics is mediated by the metabolic intermediates including kynurenine and tryptophan [38]. In solid tumors, the overexpression of tryptophan-degrading enzymes, including indoleamine-2, 3-dioxygenase (IDO1) and tryptophan-2, 3-dioxygenase (TDO2), catalyzes tryptophan to its derivative, kynurenine [38]. This tryptophan depletion is associated with the apoptosis of effector T cells, within the TME [39]. Additionally, kynurenine promotes the migratory and immunosuppressive characteristics of Tregs through aryl hydrocarbon receptor (AhR)-dependent manner [40]. The overall effect of metabolism in the TME is depicted in Fig. 1a.

\section{Tregs in the tumor microenvironment}

Tregs are key immunosuppressive players, which impede anti-tumor immune responses in the TME [41]. Within the TME, there is cross-talk among Treg and other immune cells, stromal cells, and tumor cells to maintain hypoxic, pro-angiogenic and highly immunosuppressive milieu [4, 8]. Tumor-infiltrating Tregs primarily comprise terminally differentiated and highly suppressive FoxP3high effector Tregs [42]. However, Treg heterogeneity impacts disease outcome across various cancers. Accumulation of FoxP3 ${ }^{+}$ Tregs in the TME is concomitant with higher Treg to effector $\mathrm{T}$ cell (Teff) ratios, and lower levels of naïve $\mathrm{T}$ cells and is associated with worse disease outcomes in various malignancies [43]. However, elevated levels of tumor-infiltrating Tregs have also been associated with good prognosis in certain cancers such as colorectal (CRC) and gastrointestinal cancers [8]. This could be due to Tregs capacity to suppress inflammation in initial stages, associated with disease progression of these cancers. Moreover, this inconsistency can also be attributed to the infiltration of non-suppressive, CD45RA ${ }^{-}$FoxP $3^{\text {Low }}$ non-Tregs [44]. Importantly, CRC patients with high levels of effector Tregs exhibited poorer prognosis, while a better prognosis was reported in CRC patients with predominantly higher levels of non-Tregs, who also showed high mRNA levels of TGF- $\beta$, TNF- $\alpha$ and IL-12 [45].

Tregs are recruited in the TME by various chemokines including CCR4/8/10 and CCL9/10/11 [8, 46], and expand in the TME in response to various tumor-derived factors [8]. High levels of IL-10, TGF- $\beta$ and adenosine in the TME promote expansion of natural/thymic Tregs (nTregs) and generation of peripheral Tregs (pTregs) [47, 48]. However, it remains unclear whether Tregs in the TME are trafficked to tumors or are expanded from tissue-resident Tregs [49]. In pancreatic cancer, it has been reported that Tregs are the key source of TGF- $\beta$, while their depletion could reprogram fibroblast populations and lead to tumor progression [50]. Moreover, depletion of Tregs leads to upregulation of CCL3, CCL6 and CCL8, and recruitment of immunosuppressive myeloid cells into the TME to favor tumor progression [50]. Furthermore, analyses of TCR repertoire of circulating, tissue-resident and tumor-infiltrating Tregs showed slight overlap with some distinct features in tumor-infiltrating Tregs [51]. Compared with circulation or lymph nodes, tumorinfiltrating FoxP $3^{\text {high }}$ effector Tregs are highly activated and express high levels of activation molecules including CD25, ICOS, PD-1, CTLA-4, OX40, GITR and TIGIT [41, 52].

Tumor-infiltrating Tregs suppress proliferation of other effector $\mathrm{T}$ cell populations via contact-dependent mechanisms and contact-independent mechanism, primarily through IL-10 and TGF- $\beta$ secretion [4]. IL-10 and TGF- $\beta$ secretion suppresses IFN $\gamma$ and IL-2, which are required for $\mathrm{T}$ cell activation and survival within the TME [53, 54]. In addition, secretion of IL-35 by Tregs leads to inhibition of T cell proliferation within the TME [55]. CTLA-4 presents as a homolog of CD28 and is constitutively expressed on Tregs [56]. Interactions between CTLA-4 and CD80/86 on APCs prevent costimulatory signals from CD28 for T cell activation, leading to inhibition of proliferation and cytokine release of effector T cells within the TME [57]. In addition, LAG-3 expression on tumor-infiltrating Tregs and interactions with MHC class II lead to impaired DC maturation and inhibition of proliferation of effector $\mathrm{T}$ cell populations [58]. MHC class II interactions are also hampered by increased expression of neuoropilin-1(NRP1) on Tregs, which enhance the suppressive activity and block interactions between APCs and effector T cells via enduring interactions between DCs and Tregs [59, 60]. Lastly, granzyme and perforin expression by tumor resident Tregs induces cytotoxic $\mathrm{T}$ cell and NK cell death within the TME in murine models [61].

In addition to immune functions of Tregs in the TME, their potential non-immunologic roles to support tumor progression include supporting angiogenesis, tumor growth/proliferation and transition to metastasis [62-65]. Treg levels in the TME have been correlated with high levels of VEGF [66] and promote angiogenesis by 
A

Tumor microenvironment

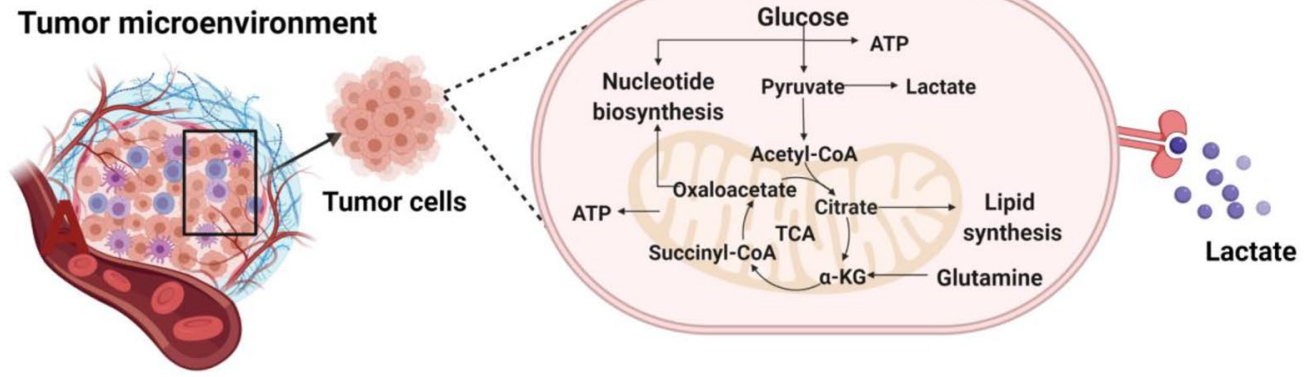

(1)

Cell migration and invasion

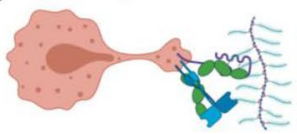

(4)

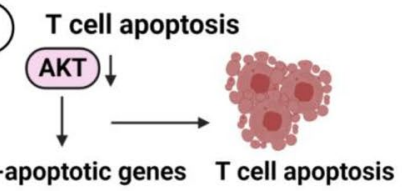

(2)

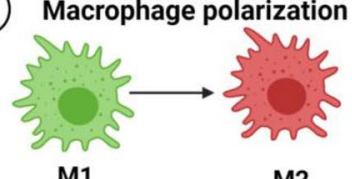

(3) HIF1a-mediated Treg migration

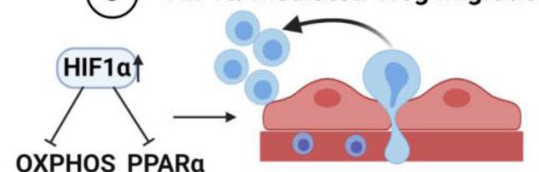

(5)

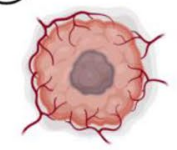

(6) iTreg polarization

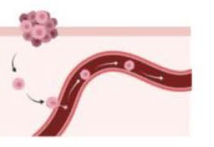

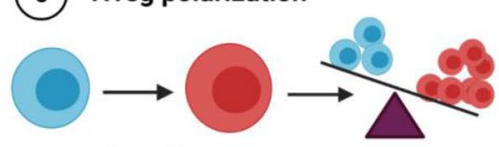

Conventional T cell pTreg

B

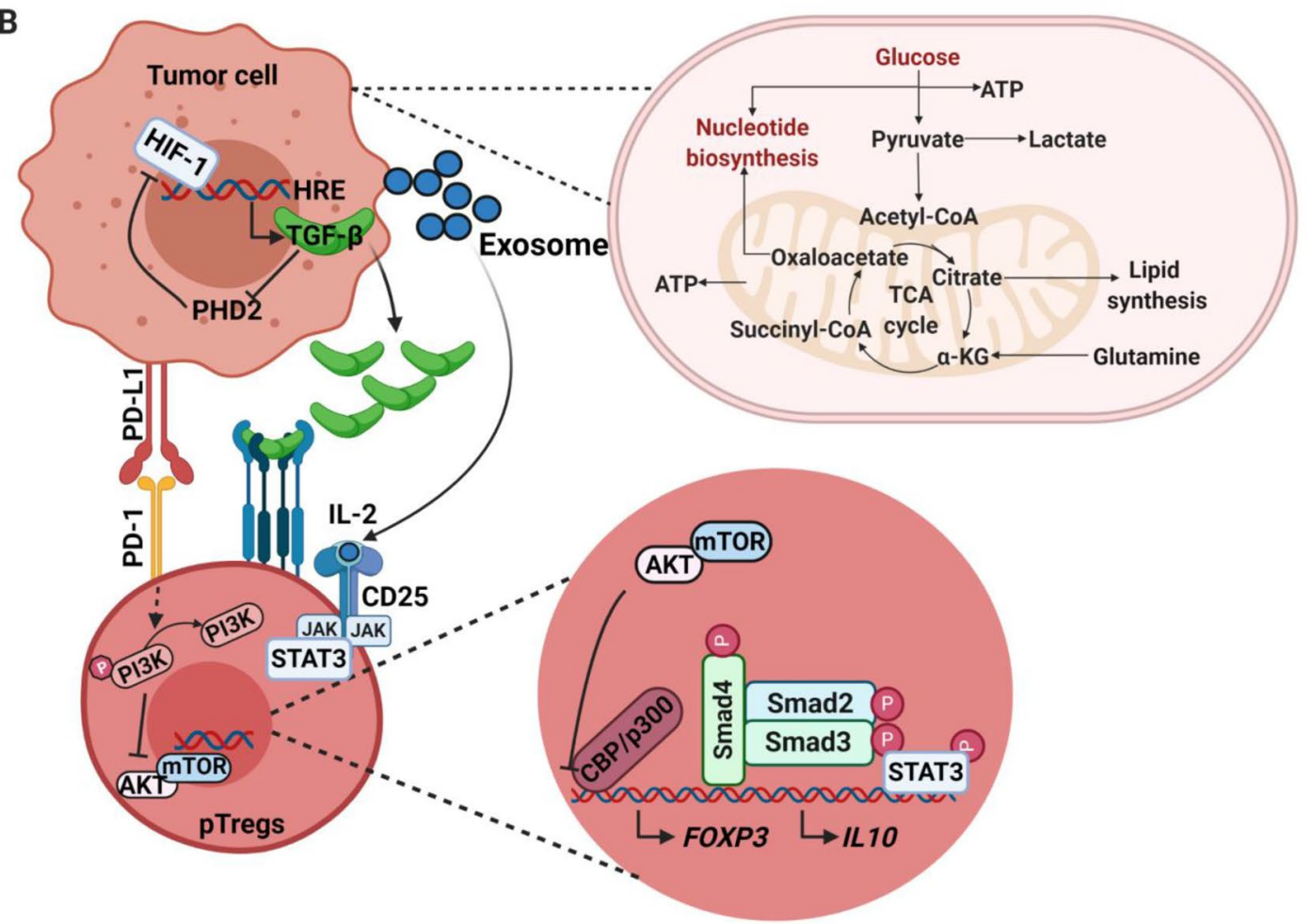

suppression of effector T cells and release of TNF $\alpha$ and IFN $\gamma$ along with other chemokines such as CXCL9, 10 and 11 [62]. Moreover, murine cancer models have shown that depletion of $\mathrm{CD} 25^{+}$Tregs enhanced anti-tumor responses, which correlated with reduction in tumor volume [67].
Other groups have revealed plausible pathways affected by tumor-infiltrating Tregs to support invasion and metastasis in different cancers. For instance, Tan et al. showed that Tregs promote invasion and metastasis in mammary cells via activation of receptor activator of nuclear factor- $\kappa B$ ligand (RANKL) signaling [11], while, Shi et al. showed 
४Fig. 1 Metabolic effects within the TME (a). Tumor cells consume major fraction of glucose and accelerate glycolysis, leading to the accumulation of lactate. The secreted lactate could influence cell types within the TME by activating multiple processes for the survival and proliferation of tumor cells. Higher glycolysis rate within the TME leads to the accumulation of lactate and induces various cellular and molecular events, including the upregulation of hyaluronic acid within the TME and favors tumor migration (1); activation of non-immunosuppressive macrophages (M1) to immunosuppressive M2 (2); upregulation of HIF-1 $\alpha$ on Tregs could inhibit OXPHOS and PPAR $\alpha$ signaling and favors the migration of Tregs into the TME (3); inhibition of AKT signaling network and induce apoptosis of activated $\mathrm{T}$ cells (4); promotion of angiogenesis and metastasis (5); polarization of conventional $\mathrm{T}$ cells to pTregs through the upregulation of TGF- $\beta$, HIF- $1 \alpha$, IL-10 and inhibition of AKT/mTOR pathway (6). Generation of pTregs within the TME (b). In hypoxic TME, HIF-1 binds to the hypoxia inducible response element (HRE) of tumor cells and activates the secretion of TGF- $\beta$. The secreted TGF- $\beta$ also favors HIF-1 expression by inhibiting HIF-1 degradation enzyme PDH 2. Moreover, the secreted TGF- $\beta$ binds to its receptor on pTregs and triggers downstream pathways, including the phosphorylation of SMAD3, binding of phospho-SMAD3 to SMAD4, recruitment of $\mathrm{CBP} / \mathrm{p} 300$ and binding of these complex on FoxP3 promoter to induce the expression of FoxP3. In addition, PD-L1 is also the downstream target of HIF-1, which could bind to PD-1 on T cells. PD-1/ PD-L1 interaction could activate the dephosphorylation of PI3K and block AKT/mTOR pathway. This signaling network helps to stabilize the expression of FOXP3. Moreover, tumor-derived exosomes could activate JAK/STAT3 pathway and favors the upregulation of IL-10. Altogether, hypoxic TME favors the polarization of conventional $\mathrm{T}$ cells to pTregs via multiple signaling cascades

that tumor-infiltrating Tregs promote invasion of hepatocellular carcinoma via epithelial-mesenchymal transition induced by TGF- $\beta 1$ secretion [68].

Because of the multi-faceted roles in tumor development and progression across different cancers, tumorinfiltrating Tregs are key targets for multiple therapeutic strategies aimed to counter immunosuppression and promote immune stimulation for clinical benefits.

\section{Metabolic pathways affecting Treg function in the hypoxic TME}

The TME is a dynamic niche orchestrated by heterogeneous metabolic activity of cells with variable vascularity that generate regions of gradient hypoxia. The metabolic features include glycolysis, oxidative stress, OXPHOS, FAO, Warburg effect and amino acid metabolism which can influence the behavior and function of Tregs.

\section{Treg survival in TME}

The metabolic adaptation in TME favor Treg survival in a hostile environment. Recent studies have shown that Tregs exhibit low membrane expression of glucose transporter
GLUT-1 along with increased lipid oxidation activity when compared to other effector $\mathrm{T}$ cell subsets [37]. Tregs and Teffs exhibit distinct metabolic patterns; the former require glycolysis, and the latter require lipid oxidation for their survival and function [37]. Indeed, Tregs favorably rely on FAO and OXPHOS, especially in lowglucose, high lactate environments with increased NAD/ NADH ratios [37]. On the other hand, the pharmacological inhibition of AMPK/lipid metabolism using Etomoxir can reduce in vitro generation of Tregs [37]. This metabolic preference is regulated by the expression of Treg transcription factor FoxP3 that further dampens glycolytic enzymes and Myc expression [69].

\section{Treg migration into TME}

Several metabolic pathways influence Treg migration into the TME. Signaling through CD28 and CTLA-4 ligands has been reported to enhance the migration of Tregs via activation of PI3K-mTORC2 pathway that upregulates glucokinase (GCK) expression, underlying the significance of glycolysis in Treg migratory phenotype in murine models [70]. Furthermore, in vitro migration assays of gliomaproduced HIF-1 $\alpha$ KO Tregs showed an inhibited migratory response to CCL22 chemotactic agent in GL-261 murine glioblastoma model [71]. On the other hand, high expression levels of amino acid-degrading enzymes including IDO and arginase 1 have been associated with increased Treg infiltration in CRC [72], hepatocellular carcinoma (HCC) [73] and uterine cervical cancer [74]. In concordance with these data, suppression of mTOR decreased IDO1 expression and activity, leading to decreased recruitment of Tregs in the TME in a murine model of medulloblastoma [75].

\section{Treg expansion in TME}

Increased frequency of Tregs in the TME has been associated with a higher proliferation rate of these cells in MCA38 CRC murine model. In this context, signaling via OX40/ OX40L has been shown to upregulate SCD1, PMVK and PPAR $\gamma$, culminating in increased synthesis of monounsaturated fatty acids and cholesterol that are essential for Treg expansion [76]. Similarly, IDO1-kynurenine pathway stimulates expansion of Tregs in a rapamycin-dependent manner [75].

\section{Treg effector functions in TME}

Several metabolic cues have been shown to influence effector Treg functionality. In this regard, hypoxic environments 
enhance Treg effector function. As demonstrated in a mouse glioma model, HIF- $1 \alpha$ stabilization in Tregs leads to a shift toward FAO and glutaminolysis supported by an upregulation of lipid transporters CD36, SLC27A1 and SLC27A4 and decreased glucose oxidation [36]. This increased uptake of lipid is pivotal to suppressive function of Tregs, demonstrated by reduced proliferation of $\mathrm{CD} 8^{+} \mathrm{T}$ cells in HIF- $1 \alpha$ KO Tregs [36], whereas treatment with Etomoxir, a mitochondrial inhibitor, depleted $\mathrm{CD} 4^{+} \mathrm{Foxp} 3^{+} \mathrm{T}$ cells population and enhanced antitumor immunity [36]. Genes of pyruvate dehydrogenase kinase 1 (PDK1) and lactate dehydrogenase A (LDHA) were upregulated in Tregs from WT mice but not in HIF-1 $\alpha$ KO mice [36]. Recent studies have also shown that elevated glucose metabolism alters Treg functionality. In a study of human tumors, glycolytic genes including Hexokinase 2 (Hk2), glyceraldehyde 3-phosphate dehydrogenase (Gapdh), and Alpha-enolase (Eno1) had higher expression levels in Tregs [76]. In another study, TLR8 signaling selectively inhibits glucose uptake and glycolysis in human Tregs via a downregulation of mTORC1-HIF1a signaling, resulting in reversal of Treg suppression [77]. Indeed, treatment with inhibitors for glucose transporters, glycolysis, cholesterol as well as isoprenoid lipid synthesis have blocked Treg suppressive functions including proliferation of responder $\mathrm{T}$ cells and increased number of senescent $\mathrm{CD} 4^{+} \mathrm{T}$ cell population [77]. In addition, adoptive transfer of $\mathrm{T}$ cells in a murine model of melanoma enhanced TLR8-dependent tumor regression [77]. However, in B16-F10 melanoma model, deletion of mTORC1 showed reduction in glycolysis and TCA cycle metabolism, while mTORC1-deficient Tregs decreased the expression of suppressive receptors such as CTLA4, ICOS and PD-1 [78]. Transcriptomic analyses of Tregs isolated from human melanomas demonstrated an increased expression of mitochondrial arginase 2 (ARG2) enzyme and enhanced Treg suppressive capacity [79].

Additionally, several tumor models including mice with ID8 ovarian cancer, MC38 colon cancer, and B16 melanoma have revealed altered Treg biological behavior characterized by substantial Treg apoptosis and potent immunosuppressive phenotype along with efficient inhibition of IL-2 production in effector $\mathrm{T}$ cells. Interestingly Treg immunosuppression was not mediated via typical suppressive pathways including CTLA-4, TGF- $\beta$, IL-35, or IL-10; instead, it was induced through adenosine production from ATP via CD39 and CD73 signaling [80]. These apoptotic Tregs exhibited an increased susceptibility to reactive oxygen species, which highlights the role of oxidative stress in TME and Treg function [80]. However, selective inhibition of fatty acid-binding protein (FABP5) in ex vivo human natural Tregs triggers mitochondrial DNA release accompanied by disruption in lipid metabolism and oxidative phosphorylation, promoting IL-10-mediated Treg suppressive function [81]. Intriguingly, impairment in electron transport chain (ETC) Complex I and
NADH oxidation decreases Treg function [69]. Similarly, loss of mitochondrial complex III lead to decreased expression of genes related to Treg function and suppressive capacity but not proliferation or survival. While RISP (an essential subunit of mitochondrial complex III) KO CD2 $5^{+}$Foxp $^{+}$ mice have shown inhibition of melanoma growth mediated by Treg loss of function under the influence of ten-eleven translocation (TET) family of DNA demethylases [82]. In particular, DNA methylation, 2-hydroxyglutarate (2-HG) and succinate negatively regulated the expression of genes involved in Treg functionality [82].

Other metabolic cues induce an immunosuppressive phenotype in CNS tumors. The constitutive PPAR expression demonstrated increased tumor burden accompanied by an expansion of Treg repertoire in murine models of astrocytoma and oligoastrocytoma [83]. Interestingly, Tregs captured fatty acids threefold higher than $\mathrm{CD} 8^{+} \mathrm{T}$ cells in intracranial murine astrocytoma [84]. In a B16 melanoma model, neuropilin-1 (Nrp1) induced intra-tumoral Treg stability by enhancing quiescence/survival genes, while inhibiting transcriptomic signatures that promote differentiation [85].

\section{Metabolic pathways involved in heterogeneity of Tregs in the TME}

Tregs exhibit distinct tissue-specific heterogeneity in inflammatory conditions and cancer. The reason behind this heterogeneity could be the association of Tregs with tissue-specific transcription factors including PPAR $\gamma$ and GATA3 [86]. Tumor-associated Tregs are often seen at the effector state with distinct metabolic signatures from lymphoid resident Tregs [86]. Cancer cells modify numerous environmental factors and nutrients within the TME, which affects the differentiation and function of tissueresident Tregs. It has been reported that a sub-population of Tregs in the brain TME express higher level of fatty acid transporters including SLC27A1 and CD36, which favors immunosuppression [36]. However, the attenuation of fatty acid intake inhibits the immunosuppressive characteristics of Tregs in the brain TME [36]. Under physiological conditions, the major energy source of tissue-resident Tregs for their proliferation and function is mediated by mTOR-dependent lipogenesis [87]. Likewise, in the CRC TME, Tregs utilize fatty acid metabolism as a key energy resource to complement glucose metabolism, leading to the accumulation of lipid-intermediates within the TME [76]. It has been reported that OX $40^{+}$Tregs were accumulated in the visceral adipose tissue (VAT) of obese CRC patients, proposing that VAT might act as a reservoir for $\mathrm{OX} 40^{+}$Tregs, which subsequently could be migrated to the TME via chemotaxis [88]. A study on 
plasmacytoid dendritic cells (pDCs) from breast cancer patients showed that excessive accumulation of lactate in the TME enhances tryptophan metabolism and kynurenine secretion by pDCs, leading to the induction of FoxP3 ${ }^{+}$ Tregs [89].

It has been reported that Tregs in the CRC TME have Th17 like phenotype, expressing ROR $\gamma \mathrm{t}$ with elevated IL-17 release [90, 91]. These ROR $\gamma \mathrm{t}^{+} \mathrm{FoxP}^{+}$Tregs have more stable and immunosuppressive characteristics, compared with ROR $\gamma \mathrm{t}^{-}$FoxP3 ${ }^{+}$Tregs [91]. Subsequently, studies showed that numerous intermediates from cholesterol metabolism including 24-dehydrocholesterol reductase, 7-dehydrocholesterol reductase act as an agonist for $\mathrm{ROR} \gamma \mathrm{t}^{+}$in inflammatory conditions [92]. These reports suggest that $\mathrm{Th} 17^{+}$effector Tregs found in the CRC TME could be regulated by cholesterol biosynthesis and accumulation of lipid-intermediates. Likewise, highly activated and proliferative Tregs in breast, colorectal, lung and melanoma TME express higher level of CCR8 and is associated with poor survival [51]. Additionally, it has been reported that the tissue-resident Tregs require higher lipid uptake for their function and survival [93].

Accumulating studies demonstrate the cytotoxic properties of circulating and in vitro generated $\gamma \delta \mathrm{T}$ cells $(\gamma \delta \mathrm{Tc})$, while the functional characteristics of tumor-infiltrating $\gamma \delta \mathrm{Tc}$ vary $[94,95]$. As mentioned in previous sections, the metabolic microenvironment of the tumor is different with the high supplement of TGF- $\beta 1$ and IL-10 [4]. This milieu might favor tumor-infiltrating $\gamma \delta \mathrm{Tc}$ to acquire certain suppressive characteristics and termed as " $\gamma \delta \mathrm{T}$ regulatory cells ( $\gamma \delta$ Tregs)". It has been reported that two subpopulations of $\gamma \delta \mathrm{Tc}(\mathrm{V} \delta 1 \mathrm{Tc}$ and $\mathrm{V} \delta 2 \mathrm{Tc}$ ) have suppressive characteristics with induced FoxP3 expression [96]. However, in renal carcinoma, it has been reported that the expression of FoxP3 was higher in tumor-infiltrating V81Tc, compared with V82Tc [97]. Additionally, the percentage of FoxP $3^{+} \gamma \delta \mathrm{Tc}$ is inversely correlated with $\mathrm{CD} 8^{+}$ TILs, confirming the anti-tumor immunosuppressive role for $\gamma \delta \mathrm{Tc}$ and poor clinical outcome [98]. Reports suggest that accumulation of $\gamma \delta \mathrm{Tc}$ in the TME could be due to the elevated metabolite flux of the mevalonate pathway intermediates [99, 100]. Moreover, isopentenyl diphosphate (IPP), a metabolic intermediate of mevalonate pathway, binds to butyrophilin 3A1 (BTN3A1) and activates $\gamma \delta \mathrm{Tc}$ [101]. Moreover, IPP-stimulated V82Tc in the presence of exogenous TGF- $\beta 1$ and IL- 15 could induce the expression of FoxP3 [102]. Altogether, these reports suggest that tumor metabolic milieu could favor the heterogeneity of Tregs, and dampen anti-tumor immune responses.

\section{Metabolic regulations behind the induction of Tregs in the hypoxic TME}

Within the TME, pTregs are generated from naïve $\mathrm{CD} 4^{+} \mathrm{T}$ cells in response to tumor antigens and other stimulatory networks [103]. These induced Tregs have a profound suppressive function alike nTregs [65]. Moreover, studies on tumor antigen-specific Tregs demonstrated that preferential accumulation of pTregs is induced by tumor antigens within the TME could potentially suppress therapeutic vaccinations $[103,104]$.

Apart from tumor antigens, TME plays an indispensable role to support the generation and accumulation of pTregs. TGF- $\beta$, which favors pTregs generation, is involved in the downstream network of HIF- $1 \alpha$ and was upregulated in hypoxic microenvironment [105]. The expression of TGF- $\beta$ and HIF- $1 \alpha$ favors each other; HIF- 1 promotes the expression of TGF- $\beta$ in CD $4^{+}$T cells, and TGF- $\beta$ attenuates the expression of HIF-1 degrading enzyme prolyl hydroxylase domain 2 (PHD2) and indirectly favors the stability of HIF-1 (Fig. 1b) [105, 106]. A hypoxic microenvironment not only promotes the expression of TGF- $\beta$ in $\mathrm{CD}^{+} \mathrm{T}$ cells, but also their internalization into the cytoplasm. In cytoplasm, TGF- $\beta$ binds to its receptor and triggers downstream pathways including phosphorylation of SMAD3, binding of phospho-SMAD3 to SMAD4, recruitment of $\mathrm{CBP} / \mathrm{p} 300$ and binding of these complex on FoxP3 promoter to induce the expression of FoxP3 (Fig. 1b) [107]. Apart from TGF- $\beta$, PD-L1 is also a downstream target of HIF-1 $\alpha$. In a hypoxic microenvironment, the expression of PD-L1 on tumor cells was upregulated by HIF- $1 \alpha$ and augments their binding with its receptor, PD-1, on T cells [108, 109]. The PD-1/PD-L1 interaction could dephosphorylate PI3K and attenuate the activation of AKT/mTOR pathway, thereby promoting the expression of FoxP3 (Fig. 1b) [108, 109]. Additionally, tumorderived exosome-mediated release of IL-10 will activate JAK/STAT-3 pathway and stabilizes FoxP3 expression and differentiation of pTregs (Fig. 1b) [110]. Moreover, tumor-derived exosomes not only release IL-10, but also upregulate microRNA-214 (miR-214) [111]. miR-214 enters into $\mathrm{T}$ cells through endocytosis and attenuates PTEN pathway and activates PI3K/AKT signaling [111]. These signaling networks activate cycle-associated transcription factor E2F and augment proliferation of nTregs [112]. On the other side, downregulation of PTEN could deplete the expression of $\mathrm{CD} 25$ leading to the accumulation of FoxP $3{ }^{+} \mathrm{CD} 25^{-}$pTregs [113].

It has been reported that TGF- $\beta$-induced Tregs express reduced level of GLUT-1 and have lower glycolysis and higher oxidative phosphorylation in the TME [76]. Moreover, the reduction in glycolysis could dampen mTOR 
signaling and favor the generation of pTregs. The switch between glycolysis to oxidative phosphorylation is considered as a key metabolic checkpoint for pTreg generation in the TME [114]. In the TME, HIF-1 $\alpha$-dependent transcriptional network facilitates glucose metabolism, which determines the polarization of $\mathrm{T}$ cell choice between pTregs and Th17; Th17 polarization requires higher glycolysis but not for pTregs [115]. Likewise, acetyl-coA carboxylase 1 (ACC1), a major enzyme in fatty acid anabolism, also determines the fate of Th17 and Treg polarization. Inhibition of ACC1 favors pTregs, while activation favors Th17 differentiation $[116,117]$. Unlike pTregs, nTregs persist in distinct tumor metabolic environment. Highly proliferative and immunosuppressive nTregs require mTOR activation and higher glycolysis and fatty acid metabolism for their survival $[118,119]$. In the tumor milieu, glucose-deprived condition favors more of pTregs than nTregs in order to balance the percentage of Tregs within the TME [103].

\section{Factors affecting the Treg metabolism}

\section{Vitamins}

Vitamins, including A, B, C and D, play important regulatory roles, which affect different metabolic pathways, modulate gene transcription and immunological responses [120]. Vitamin A metabolite, retinoic acid (RA), produced by specific subsets of dendritic cells (DCs) can regulate FoxP3 expression via direct or indirect means [121-123]. RA can directly promote FoxP3 expression by increasing histone methylation and acetylation of the conserved noncoding DNA sequence (CNS) at the FoxP3 gene locus and promoter region, and by triggering the activation of extracellular-related kinase (ERK) signaling [122]. Through indirect means, RA supports the stability of FoxP3 expression [121] and promotes Treg survival and expansion via the activation of IL-2 signaling, leading to the conversion of TGF- $\beta$-mediated $\mathrm{CD} 4{ }^{+} \mathrm{CD} 25^{+} \mathrm{FoxP} 3^{+}$Tregs from $\mathrm{CD} 4^{+} \mathrm{CD} 25^{-} \mathrm{FoxP}^{-} \mathrm{T}$ cells $[124,125]$.

Other vitamins such as $\mathrm{C}$ and $\mathrm{D}$ have also been implicated in the modulation of FoxP3 expression. Studies on induced Tregs (iTregs) demonstrated the importance of vitamin $\mathrm{C}$ in stabilizing FoxP3 expression via the induction of the TETmediated demethylation of CNS2 region, which in turn activates FoxP3 gene transcription [126, 127]. TET family proteins are enzymes, which facilitate DNA demethylation leading to the activation of gene transcription [128]. Studies have shown that deletion of both TET2 and TET3 genes is sufficient to disrupt the stability of FoxP3 expression and that deletion of TET2 gene in Tregs counteracts the effect of vitamin $\mathrm{C}$ and diminishes the suppressive activity of Tregs [126, 127, 129]. In an allogeneic skin transplantation model, vitamin C-treated allogenic iTregs exhibited a high suppressive property with increased expression of Treg gene signature and a stable expression of FoxP3 induced by the TET-mediated demethylation [130].

Vitamin D3 metabolites, 25-dihydroxyvitamin D3 [25(OH)VD3] and the active form 1,25(OH)2 VD3 are also known to induce the expression of FoxP3 in $\mathrm{CD}^{+}{ }^{+} \mathrm{T}$ cells upon the stimulation of TCR and IL-2 signaling [131, 132]. Jeffery et al. demonstrated that stimulating $\mathrm{CD} 4{ }^{+} \mathrm{CD} 25^{-} \mathrm{T}$ cells with $1,25(\mathrm{OH}) 2 \mathrm{VD} 3$ diminished the production of proinflammatory cytokines (IFN $\gamma$, IL-17 and IL-21), and in cooperation with IL-2 significantly upregulated the levels of CTLA-4 and FoxP3 [131]. Indeed, vitamin D response element (VDRE) has been found in the intronic CNS region of the human FoxP3 gene, suggesting that this region could serve as a functional enhancer for the induction of FoxP3 gene expression [133]. However, the exact mechanisms by which VDRE transcriptionally regulates FoxP3 gene remain undetermined. Data from clinical trials supported the efficacy of vitamin $D$ in promoting the expansion of peripheral Tregs in patients with inflammatory or autoimmune conditions [134], suggesting that targeting vitamin D in Tregs could offer a therapeutic efficacy in cancer patients.

Vitamin B3 is another vitamin which is known to regulate the generation of Tregs present in the colon and to maintain colonic immune tolerance $[135,136]$. Additionally, niacin, a form of Vitamin B3, triggers anti-inflammatory signals through G protein-coupled receptor (GPR) 109a, leading to expression of RA synthetases in colon macrophages and DCs, which in turn stimulate Treg differentiation [135].

\section{Metabolites}

Metabolites generated from amino acid catabolism can positively influence Treg induction and function. The expression of IDO, an enzyme which catabolizes the amino acid tryptophan and limits its availability to T cells, showed a positive correlation with Treg density in tumors, for instance in papillary thyroid carcinomas [137]. DCs expressing IDO can induce the generation of FoxP3 ${ }^{+}$Tregs from naïve $\mathrm{T}$ cells, and block the differentiation of Th17 cells [138-140]. IDO catabolizes tryptophan to kynurenine, which in turn binds to AHR and facilitates the differentiation of naïve $T$ cells to Tregs [141, 142]. Moreover, the ability of the tryptophan metabolite, 3-hydroxyanthranilic acid (3-HAA), in increasing the expression of TGF- $\beta$ in DCs and levels of Tregs and in reducing the levels of Th1 and Th17 cells has been demonstrated in vivo. Alternatively, limited availability of tryptophan mediated by IDO activity can trigger a stress response pathway via the activation of general control nonderepressing-2 (GCN2) protein kinase, resulting in the inhibition of mTORC2 and Akt activation, thereby favoring Treg differentiation/function/stability and inducing cell 
cycle arrest and anergy in T effector cells [40, 143, 144]. Collectively, these data implicate that tryptophan catabolism could be essential for the maintenance of Treg stability, and blocking this pathway could offer a therapeutic benefit for targeting Treg metabolism.

Metabolites from purine (nucleotide base) catabolism can regulate Treg induction and FoxP3 expression by the generation of extracellular adenosine triphosphate (ATP), which binds to the purinergic $\mathrm{P} 2 \mathrm{X} 7$ receptor, and leads to the disruption of FoxP3 stability and promotion of Treg conversion to Th17 cells [145]. However, excess extracellular ATP can be converted by $\mathrm{CD} 39^{+} \mathrm{CD} 73^{+}$Tregs into immunosuppressive adenosine [146, 147]. Adenosine in turn acts on effector $\mathrm{T}$ cells via the binding to its receptor (A2AR) and exert suppressive functions, including the inhibition of TCR signaling and the induction of cell cycle arrest [148, 149]. Thus, targeting metabolic pathways resulting in excess production of ATP could be important to control the adenosine-mediated immunosuppression pathway.

\section{Targeting Treg metabolism or metabolic pathways}

Conventional cancer therapeutic strategies such as chemotherapy and radiotherapy can effectively reduce the number of activated Tregs and increase the number of effector $\mathrm{T}$ cells in cancer patients [150-152]. For instance, Cao et al. reported that gamma irradiation can reduce the suppressive function of Tregs by downregulating the expression of FoxP3 and membrane TGF- $\beta$ [153]. Moreover, clinical trials showed the efficacy of chemotherapy in reducing the frequency of $\mathrm{CD} 4{ }^{+} \mathrm{CD} 25^{+} \mathrm{FoxP} 3^{+}$Tregs and their suppressive function in the circulation of patients with hepatocellular carcinoma [154] and in tumor tissues of breast cancer patients [155]. However, there are multiple potential risks associated with cytotoxicity, which can arise from using chemotherapeutic and radiotherapeutic drugs as these strategies could also affect the number of effector $T$ cells and negatively modulate anti-tumor immunity $[152,156]$. Additionally, evidence from animal models suggests that emergence of Treg resistance against radiotherapy is mediated by the overexpression of glucocorticoid-induced tumor necrosis factor receptor family-related protein (GITR) and increased production of TGF- $\beta$ [153, 157]. In addition, a study by Muroyama et al. showed that radiotherapy in tumorbearing mice increased the suppressive function and proliferation of tumor-infiltrating Tregs and the expression of inhibitory immune checkpoints, such as CTLA-4, on Tregs [158]. Schuler et al. reported increased frequency of circulating Tregs and Treg suppressive function in patients with head and neck squamous cell carcinoma (HNCC) following chemo-radiotherapy [159], while Oweida et al. showed that tumor-infiltrating Tregs can induce resistance against radiotherapy in mouse HNCC model and their blockade using anti-CD25 mAb in combination with radiotherapy showed better clinical outcomes [160]. Therefore, these latter findings indicate that identifying Treg-targeting agents is crucial to maximize anti-tumor efficacy and specifically deplete Tregs with minimal or no adverse effects on effector T cells.

Effects of chemotherapy and radiotherapy on Treg metabolic reprograming have not been yet reported. Nonetheless, Treg metabolism could be targeted via the inhibition of various metabolism-related signaling mediators, such as PTEN, HIF- $1 \alpha$, TGF- $\beta$ and AMPK, in addition to key enzymes which facilitate fatty acid metabolism (such as ACC1) or amino acid catabolism (such as IDO) as described below.

$\mathrm{PI} 3 \mathrm{~K} / \mathrm{AKT} / \mathrm{mTOR}$ signaling pathway is amongst the key pathways, which controls metabolic reprogramming in Tregs and negatively regulates Treg suppressive function. Conversely, the inhibition of PI3K/AKT/mTOR pathway promotes the programming of immunosuppressive Tregs [161, 162]. Studies have shown that inhibiting the activity of specific isoforms of PI3K or mTORC1 (target of rapamycin complex 1) can diminish the expression of inhibitory immune checkpoints such as PD-1 and CTLA-4 and negatively influence Treg phenotype [78, 163]. A study by Kanamori et al. reported that $\mathrm{FoxP}^{+}$Tregs can be generated upon the reprogramming of Th1 cells via therapeutic intervention targeting the activation of PI3K/AKT/mTOR pathway, causing a metabolic shift from glycolysis to OXPHOS [164]. Another study by Basu et al. showed that Treg stability can be disrupted by the pharmacological activation of AKT, which in turn leads to an increase in glucose uptake and glycolysis [165]. The stability of Tregs and their suppressive phenotype requires PTEN (phosphatase and tensin homolog), a key negative regulator of PI3K/AKT signaling, which restrains the capacity of Th1 and follicular T helper cell polarization $[113,166]$. Studies have shown that FoxP3 instability in PTEN-deficient Tregs is more likely to occur as a result of increased glycolysis and reduced OXPHOS [113, 144, 166]. A study in melanoma mouse model showed that PTEN is required for the IDO-induced Treg activation and stability [144]. It was shown that IDO inhibits the phosphorylation of serine residue 473 on AKT and mTOR/TORC2 complex and hence hampers their activation [144]. On the other hand, in vivo administration of IDO inhibitor in tumorbearing mice resulted in the phosphorylation of Akt in Tregs [144]. PD-1 expressed by activated Tregs is another inhibitor of AKT through the activation of PTEN and therefore has been implicated in Treg stability [167, 168]. Altogether, these findings suggest that targeting PTEN, IDO and PD-1 signaling pathways in Tregs can lead to metabolic programming switching from lipid oxidation to glycolysis via the activation of PI3K/AKT/mTOR signaling in activated Tregs (Fig. 2). Since CTLA-4 is constitutively expressed by Tregs 


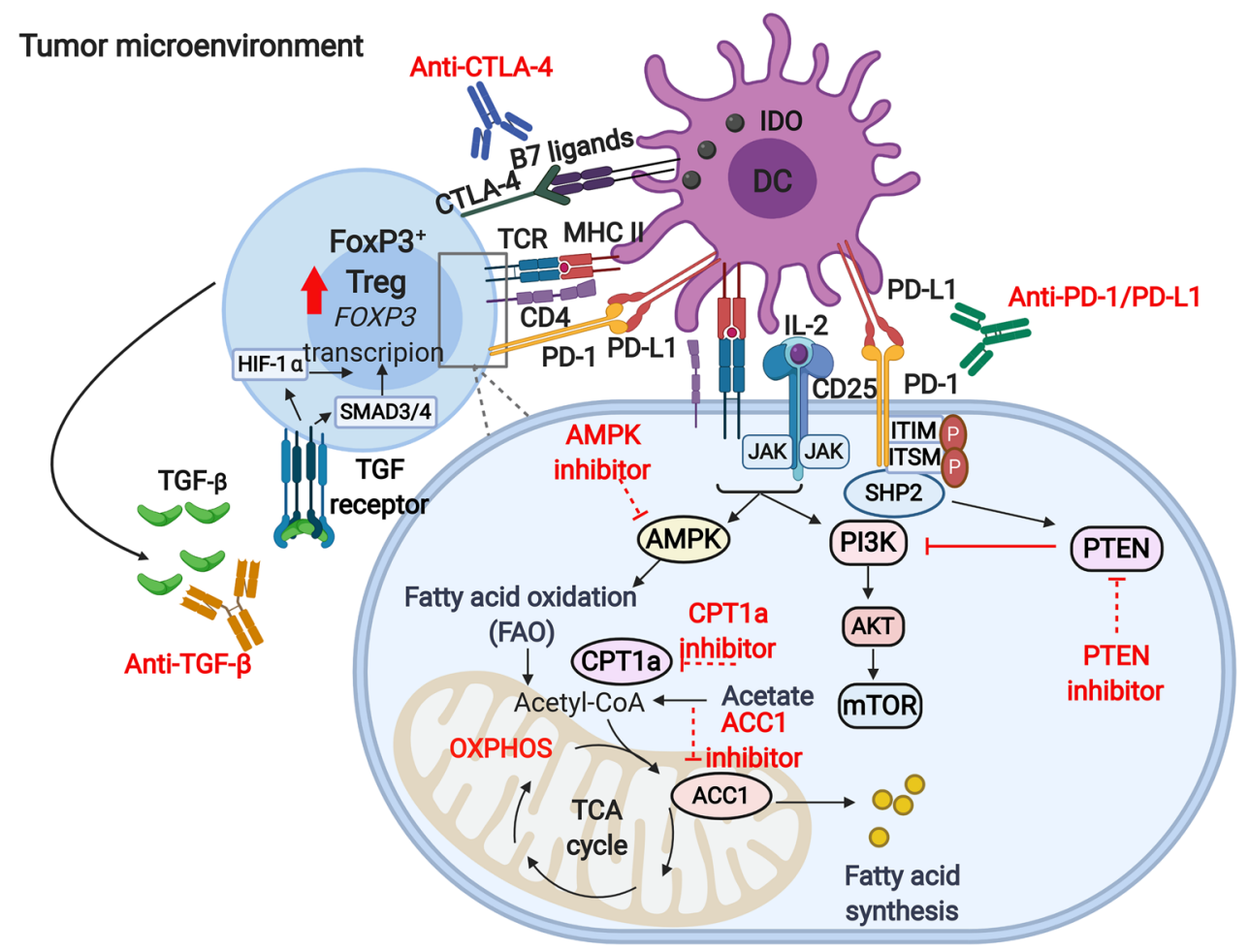

Fig. 2 Strategies for targeting Treg metabolism. The accumulation of high numbers of Tregs within the tumor microenvironment could be governed by the action of various mediators and signaling pathways. Direct interactions between tolerogenic DCs and Tregs results in the activation of TCR-mediated signaling pathway. Moreover, the interactions between CTLA-4 on Tregs and B7 ligands on DCs induces IDO expression, an enzyme which facilitates tryptophan catabolism and limits its availability to $\mathrm{T}$ effector cells. Metabolites from tryptophan catabolism can be also important for Treg induction and FoxP3 stability (not shown here). IL-2/CD25 signaling is essential for the survival and proliferation of Tregs, as it leads to the downstream activation of PI3K/AKT/mTOR signaling and STAT5 signaling. PD-1/PD-L1 signaling, on the other hand, suppresses the activation of PI3K/AKT/ mTOR via PTEN, thereby favoring FoxP3 expression and stability. TCR-mediated signaling in cooperation with IL-2 signaling triggers the activation of AMPK, a critical protein kinase for lipid metabolism and FAO, which are required for energy production, and Treg

and may play a key role in stabilizing FoxP3 expression via the induction of IDO expression [56, 57, 149]; hence, targeting CTLA- 4 could be beneficial in altering Treg programing and disrupting Treg stability (Fig. 2).

$\mathrm{T}$ cell metabolism is a highly dynamic process and can be mimicked in vitro using experimental conditions, which include the optimization of TCR signal strength (dose and duration) and the presence of cytokines or drugs $[169,170]$. The metabolic requirements for Treg differentiation in vitro under the influence of cytokines have been well studied; however, less is known about the metabolic factors required for Treg induction in vivo. Highly activated immunosuppressive Tregs rely on fatty acid metabolism, rather than glycolysis; hence, targeting enzymes which facilitate fatty survival and function. ACC1 is an enzyme which facilitates fatty acid synthesis, while CPT1a is responsible for FAO. Activated, highly immunosuppressive Tregs can release high levels of TGF- $\beta$, which is a key mediator for Treg survival, function and differentiation. Via an autocrine signaling, the activation of TGF- $\beta$ signaling in Tregs can induce HIF- $1 \alpha$ expression and trigger the activation of SMAD3 and 4 signaling, which subsequently prompt FoxP3 expression and Treg function. Targeting PD-1 and CTLA-4 signaling by mAbs could be beneficial in reducing FoxP3 stability and diminishing Treg numbers. Small molecule inhibitors targeting PTEN, ACC1 and CPT1a could offer a therapeutic benefit in cancer by destabilizing FoxP3 expression and suppressing Treg function. Moreover, the neutralization of TGF- $\beta$ could block the HIF-1 and SMAD-mediated FoxP3 induction, and the inhibition of AMPK activity could be beneficial in depleting Tregs and disrupting FoxP3 expression. Potential therapeutic inhibition strategies are indicated by dotted red lines

acid metabolism, such as ACC1, could offer a therapeutic benefit in cancer by depleting activated Tregs. The requirement of lipid uptake and oxidation for FoxP3 expression in $\mathrm{T}$ cells has been determined through the use of etomoxir, a small molecule inhibitor, which targets fatty acid oxidation (FAO) selectively by inhibiting the activity of carnitine palmitoyltransferase 1a (CPT1a), resulting in the abrogation of FoxP3 expression [37, 171]. Moreover, pharmacological inhibition of enzymes regulating the generation or signaling of fatty acid derivatives such as estrogen-related receptor- $\alpha(E R R \alpha)$ can also impair Treg differentiation and function in vitro [172]. On the contrary, the differentiation of Tregs can be rescued upon the addition of fatty acids to in vitro cultures resulting in the upregulation of ERR $\alpha$ and 
lipid oxidation [172]. These data implicate that pharmacologic inhibitors targeting FAO could be potentially used to block Treg programing and disrupt their stability by affecting FoxP3 expression (Fig. 2).

Hypoxia and HIF1- $\alpha$ can be also involved in the induction of FoxP3 expression [24, 25, 105]. However, some studies have demonstrated that HIF1- $\alpha$ expression can impair Treg stability in vivo as it induces the transcription of glycolytic genes and promotes FoxP3 degradation [115, 173, 174]. Suppression of HIF1- $\alpha$ function via the activation of oxygen-sensing prolyl-hydroxylase (PHD) results in the induction of Treg programming in metastatic niches [175]. Alternatively, targeted deletion of the HIF1- $\alpha$ E3 ubiquitin ligase in Tregs can increase the expression of HIF1- $\alpha$, which can directly bind to the promoter of the IFNG gene and trigger the expression of IFN- $\gamma$ in Tregs, resulting in their conversion into Th1-like cells $[176,177]$. Considering the mutual relationship between TGF- $\beta$ and HIF- $1 \alpha$, inhibition of TGF- $\beta$ signaling could result in effective depletion of Tregs by limiting the capacity of FoxP $3^{+}$Treg survival and differentiation [147] and increase the degradation of HIF- $1 \alpha$ (Fig. 2).

AMP-activated protein kinase (AMPK) signaling is another pathway, which can promote the generation of Tregs and diminish the numbers of Th1 and Th17 cells [37], thereby favoring immunosuppression and tumor progression. LKB1, upstream of AMPK, is another metabolic sensor, which is critical for lipid metabolism, OXPHOS, energy production and survival and function of Tregs in an independent manner of the AMPK pathway [178]. Collectively, these studies suggest that targeting AMPK or LKB1 signaling may be beneficial in regulating Treg metabolisms and disruption of Treg stability. The potential metabolic pathways, which could be targeted for the improvement of disease prognosis, are depicted in Fig. 2.

\section{Concluding remarks and future perspectives}

The physicochemical properties of the TME could be altered by nutrient availability and metabolic reprogramming of tissue-resident cells. These modifications are evident by the development of hypoxic environment and reduction in $\mathrm{pH}$, due to changes in cell-mediated transcription factors and the accumulation of metabolic intermediates [179]. Besides the biochemical cues, which have been explained throughout the above sections, physical modifications could also be greatly influenced by the metabolic alterations within the TME [180]. These physical cues could alter the cellular characteristics, including proliferation, metastatic potential and stem cell features of tumor, as well as other tissue-resident cells [180]. The major physical cues affect the extra cellular matrix (ECM) of the TME, including their pore size, alignment of fibrous tissue, cellular attachment and cross-link of collagen, which favor tumor progression [181]. Indeed, it has been reported that an intact ECM component, high molecular weight hyaluronan (HMW-HA), could stabilize FoxP3 and favor the survival and differentiation of Tregs with in the ECM [182]. Additionally, HWA-HA could enhance the suppressive function of Tregs in both in vivo and in vitro [182].

In all cases, the metabolic modifications in the TME favor tumor progression and tumor-immune evasion. In addition, immunometabolism has also been manipulated to enhance current immunotherapeutic modalities through adoptive $\mathrm{T}$ cell transfer. For instance, the metabolic potential of genetically-engineered Chimeric Antigen Receptor (CAR)-T cells or other T cells, including T effector cells, could be enhanced to overcome the deleterious effects of the TME and enhance their anti-tumor aptitude [183, 184]. Moreover, the plausible side-effects of metabolic modulators on non-malignant tissue have not been fully elucidated. However, reports showed that the deleterious effects of metabolic inhibitors are very low, compared with other drugs, perhaps due to the high metabolic plasticity of tissue-resident cells [183, 185].

This review mainly resolves three important queries (1) how does the hypoxic metabolic TME affects the function of Tregs, (2) how do pTregs benefit from the metabolic cues within the TME and (3) what possible therapeutic modalities can be employed to target the metabolic reprogramming of Tregs. Infiltration of Tregs is considered as a hallmark of the TME and can affect the progression and metastasis of tumor. The metabolic reprogramming within the TME influences Tregs in three main ways; (1) encouraging the trafficking of Tregs to the TME, (2) induction of Tregs from conventional $\mathrm{T}$ cells and (3) upregulating the immunosuppressive characteristics of Tregs. The major metabolic pathways which could influence the Tregs in the TME include tryptophan metabolism, glycolysis and fatty acid oxidation. Moreover, the metabolic reprogramming of Tregs is not limited to a certain pathway. For instance, glycolysis could affect Tregs in conflicting ways; favoring the proliferation of Tregs and attenuating their suppressive function [186]. However, the intermediate metabolites of glycolysis and tryptophan metabolism promote the regulatory function of Tregs [186].

Several factors which are indispensable for the effective function of effector T cells are restricted in the TME, while metabolic alterations favor unrestrained tumor proliferation that leads to nutrient-deprived milieu, excess accumulation of metabolic intermediates, and inadequate oxygen supply. These conditions benefit the generation of pTregs through HIF-1-dependent manner. Moreover, the reduction in glycolysis triggers AMPK-mediated mTOR inhibition, which is the foremost signaling pathway for the generation of pTregs in the hypoxic tumor milieu.

Next, we focused on the development of therapeutic modalities, which could work synergistically with current 
immunotherapies for better prognostic outcomes. Up to date, there is evidence demonstrating that utilizing $\mathrm{mAbs}$ against immune checkpoints, suppressive mediators (e.g., TGF- $\beta$ ), epigenetic modifiers and pharmacological inhibitors for protein kinases, fatty acid transporters, fatty acid metabolism-related enzymes which favor FAO pathways, Treg differentiation and suppressive functions could have a promising clinical impact in cancer patients. However, more studies utilizing advanced technologies are required to investigate the epigenetic and molecular signaling driven by metabolic reprogramming, which influence the differentiation of Tregs and their suppressive and migratory properties. For instance, single cell RNA sequencing could be adapted to uncover the molecular pathways involved in Treg metabolic reprogramming during cancer progression. Additionally, the utilization of Assay for Transposase-Accessible Chromatin sequencing (ATAC-seq) could be used to analyze the transcription factors which have key roles in regulating epigenetic mechanisms and mediate metabolic alterations shaping Treg stability, plasticity and function. Furthermore, in situ imaging and metabolic profiling could be utilized to analyze cell-to-cell communication between Tregs and other cell types to reveal novel metabolic interactions, which potentially could provide new Treg metabolic interventions for cancer treatment.

Author contributions VN, RS and ST wrote the article and prepared figures/table. FC assisted in writing-review and editing. EE conceived the concept, acquired funds, supervised and performed writing-review and editing.

\section{Compliance with ethical standards}

Conflict of interest The authors declare no conflicts of interest.

Open Access This article is licensed under a Creative Commons Attribution 4.0 International License, which permits use, sharing, adaptation, distribution and reproduction in any medium or format, as long as you give appropriate credit to the original author(s) and the source, provide a link to the Creative Commons licence, and indicate if changes were made. The images or other third party material in this article are included in the article's Creative Commons licence, unless indicated otherwise in a credit line to the material. If material is not included in the article's Creative Commons licence and your intended use is not permitted by statutory regulation or exceeds the permitted use, you will need to obtain permission directly from the copyright holder. To view a copy of this licence, visit http://creativecommons.org/licenses/by/4.0/.

\section{References}

1. Bredberg A (2011) Cancer: more of polygenic disease and less of multiple mutations? A quantitative viewpoint. Cancer 117(3):440-445. https://doi.org/10.1002/cncr.25440
2. Du G, Liu Y, Li J, Liu W, Wang Y, Li H (2013) Hypothermic microenvironment plays a key role in tumor immune subversion. Int Immunopharmacol 17(2):245-253. https://doi.org/10.1016/j. intimp.2013.06.018

3. Hanahan D, Weinberg RA (2011) Hallmarks of cancer: the next generation. Cell 144(5):646-674. https://doi.org/10.1016/j.cell. 2011.02.013

4. Whiteside TL (2008) The tumor microenvironment and its role in promoting tumor growth. Oncogene 27(45):5904-5912. https:// doi.org/10.1038/onc.2008.271

5. Tredan O, Galmarini CM, Patel K, Tannock IF (2007) Drug resistance and the solid tumor microenvironment. J Natl Cancer Inst 99(19):1441-1454. https://doi.org/10.1093/jnci/djm135

6. Syed Khaja AS, Toor SM, El Salhat H, Ali BR, Elkord E (2017) Intratumoral FoxP3(+)Helios(+) regulatory T cells upregulating immunosuppressive molecules are expanded in human colorectal cancer. Front Immunol 8:619. https://doi.org/10.3389/fimmu. 2017.00619

7. Syed Khaja AS, Toor SM, El Salhat H, Faour I, Ul Haq N, Ali BR, Elkord E (2017) Preferential accumulation of regulatory T cells with highly immunosuppressive characteristics in breast tumor microenvironment. Oncotarget 8(20):33159-33171. https://doi.org/10.18632/oncotarget.16565

8. Chaudhary B, Elkord E (2016) Regulatory T cells in the tumor microenvironment and cancer progression: role and therapeutic targeting. Vaccines Basel. https://doi.org/10.3390/vaccines40 30028

9. Curiel TJ, Coukos G, Zou L, Alvarez X, Cheng P, Mottram P, Evdemon-Hogan M, Conejo-Garcia JR, Zhang L, Burow M, Zhu Y, Wei S, Kryczek I, Daniel B, Gordon A, Myers L, Lackner A, Disis ML, Knutson KL, Chen L, Zou W (2004) Specific recruitment of regulatory $\mathrm{T}$ cells in ovarian carcinoma fosters immune privilege and predicts reduced survival. Nat Med 10(9):942-949. https://doi.org/10.1038/nm1093

10. Facciabene A, Peng X, Hagemann IS, Balint K, Barchetti A, Wang LP, Gimotty PA, Gilks CB, Lal P, Zhang L, Coukos G (2011) Tumour hypoxia promotes tolerance and angiogenesis via CCL28 and T(reg) cells. Nature 475(7355):226-230. https://doi. org/10.1038/nature10169

11. Tan W, Zhang W, Strasner A, Grivennikov S, Cheng JQ, Hoffman RM, Karin M (2011) Tumour-infiltrating regulatory T cells stimulate mammary cancer metastasis through RANKL-RANK signalling. Nature 470(7335):548-553. https://doi.org/10.1038/ nature09707

12. Wei S, Kryczek I, Edwards RP, Zou L, Szeliga W, Banerjee M, Cost M, Cheng P, Chang A, Redman B, Herberman RB, Zou W (2007) Interleukin-2 administration alters the CD4+FOXP3+ T-cell pool and tumor trafficking in patients with ovarian carcinoma. Cancer Res 67(15):7487-7494. https://doi.org/10.1158/ 0008-5472.CAN-07-0565

13. Liyanage UK, Moore TT, Joo HG, Tanaka Y, Herrmann V, Doherty G, Drebin JA, Strasberg SM, Eberlein TJ, Goedegebuure PS, Linehan DC (2002) Prevalence of regulatory T cells is increased in peripheral blood and tumor microenvironment of patients with pancreas or breast adenocarcinoma. J Immunol 169(5):2756-2761. https://doi.org/10.4049/jimmunol.169.5.2756

14. Bates GJ, Fox SB, Han C, Leek RD, Garcia JF, Harris AL, Banham AH (2006) Quantification of regulatory T cells enables the identification of high-risk breast cancer patients and those at risk of late relapse. J Clin Oncol 24(34):5373-5380. https://doi.org/ 10.1200/JCO.2006.05.9584

15. Shang B, Liu Y, Jiang SJ, Liu Y (2015) Prognostic value of tumor-infiltrating FoxP3+ regulatory $\mathrm{T}$ cells in cancers: a systematic review and meta-analysis. Sci Rep 5:15179. https://doi. org/10.1038/srep15179 
16. Bauer CA, Kim EY, Marangoni F, Carrizosa E, Claudio NM, Mempel TR (2014) Dynamic Treg interactions with intratumoral APCs promote local CTL dysfunction. J Clin Invest 124(6):2425-2440. https://doi.org/10.1172/JCI66375

17. Tada Y, Togashi Y, Kotani D, Kuwata T, Sato E, Kawazoe A, Doi T, Wada H, Nishikawa H, Shitara K (2018) Targeting VEGFR2 with Ramucirumab strongly impacts effector/ activated regulatory T cells and $\mathrm{CD} 8(+) \mathrm{T}$ cells in the tumor microenvironment. J Immunother Cancer 6(1):106. https://doi.org/10.1186/ s40425-018-0403-1

18. Phan LM, Yeung SC, Lee MH (2014) Cancer metabolic reprogramming: importance, main features, and potentials for precise targeted anti-cancer therapies. Cancer Biol Med 11(1):1-19. https://doi.org/10.7497/j.issn.2095-3941.2014.01.001

19. Hope HC, Salmond RJ (2019) Targeting the tumor microenvironment and $\mathrm{T}$ cell metabolism for effective cancer immunotherapy. Eur J Immunol 49(8):1147-1152. https://doi.org/10.1002/eji. 201848058

20. Chang CH, Curtis JD, Maggi LB Jr, Faubert B, Villarino AV, O'Sullivan D, Huang SC, van der Windt GJ, Blagih J, Qiu J, Weber JD, Pearce EJ, Jones RG, Pearce EL (2013) Posttranscriptional control of $\mathrm{T}$ cell effector function by aerobic glycolysis. Cell 153(6):1239-1251. https://doi.org/10.1016/j. cell.2013.05.016

21. Siska PJ, Beckermann KE, Mason FM, Andrejeva G, Greenplate AR, Sendor AB, Chiang YJ, Corona AL, Gemta LF, Vincent BG, Wang RC, Kim B, Hong J, Chen CL, Bullock TN, Irish JM, Rathmell WK, Rathmell JC (2017) Mitochondrial dysregulation and glycolytic insufficiency functionally impair CD8 T cells infiltrating human renal cell carcinoma. JCI Insight. https://doi.org/10.1172/jci.insight.93411

22. Kouidhi S, Elgaaied AB, Chouaib S (2017) Impact of metabolism on T-cell differentiation and function and cross talk with tumor microenvironment. Front Immunol 8:270. https://doi. org/10.3389/fimmu.2017.00270

23. Warburg O, Wind F, Negelein E (1927) The metabolism of tumors in the body. J Gen Physiol 8(6):519-530. https://doi. org/10.1085/jgp.8.6.519

24. Ben-Shoshan J, Maysel-Auslender S, Mor A, Keren G, George J (2008) Hypoxia controls CD4+CD25+ regulatory T-cell homeostasis via hypoxia-inducible factor-1alpha. Eur J Immunol 38(9):2412-2418. https://doi.org/10.1002/eji.200838318

25. Neildez-Nguyen TMA, Bigot J, Da Rocha S, Corre G, Boisgerault F, Paldi A, Galy A (2015) Hypoxic culture conditions enhance the generation of regulatory $\mathrm{T}$ cells. Immunology 144(3):431-443. https://doi.org/10.1111/imm.12388

26. Guillaumond F, Leca J, Olivares O, Lavaut MN, Vidal N, Berthezene P, Dusetti NJ, Loncle C, Calvo E, Turrini O, Iovanna JL, Tomasini R, Vasseur S (2013) Strengthened glycolysis under hypoxia supports tumor symbiosis and hexosamine biosynthesis in pancreatic adenocarcinoma. Proc Natl Acad Sci U S A 110(10):3919-3924. https://doi.org/10.1073/pnas.12195 55110

27. Pavlova NN, Thompson CB (2016) The emerging hallmarks of cancer metabolism. Cell Metab 23(1):27-47. https://doi.org/10. 1016/j.cmet.2015.12.006

28. Fischer K, Hoffmann P, Voelkl S, Meidenbauer N, Ammer J, Edinger M, Gottfried E, Schwarz S, Rothe G, Hoves S, Renner K, Timischl B, Mackensen A, Kunz-Schughart L, Andreesen R, Krause SW, Kreutz M (2007) Inhibitory effect of tumor cellderived lactic acid on human T cells. Blood 109(9):3812-3819. https://doi.org/10.1182/blood-2006-07-035972

29. Goetze K, Walenta S, Ksiazkiewicz M, Kunz-Schughart LA, Mueller-Klieser W (2011) Lactate enhances motility of tumor cells and inhibits monocyte migration and cytokine release. Int J Oncol 39(2):453-463. https://doi.org/10.3892/ijo.2011.1055
30. Colegio OR, Chu NQ, Szabo AL, Chu T, Rhebergen AM, Jairam V, Cyrus N, Brokowski CE, Eisenbarth SC, Phillips GM, Cline GW, Phillips AJ, Medzhitov R (2014) Functional polarization of tumour-associated macrophages by tumour-derived lactic acid. Nature 513(7519):559-563. https://doi.org/10.1038/nature13490

31. Constant JS, Feng JJ, Zabel DD, Yuan H, Suh DY, Scheuenstuhl H, Hunt TK, Hussain MZ (2000) Lactate elicits vascular endothelial growth factor from macrophages: a possible alternative to hypoxia. Wound Repair Regen 8(5):353-360. https://doi. org/10.1111/j.1524-475x.2000.00353.x

32. Stern R, Shuster S, Neudecker BA, Formby B (2002) Lactate stimulates fibroblast expression of hyaluronan and CD44: the Warburg effect revisited. Exp Cell Res 276(1):24-31. https://doi. org/10.1006/excr.2002.5508

33. Zhang JZ, Behrooz A, Ismail-Beigi F (1999) Regulation of glucose transport by hypoxia. Am J Kidney Dis 34(1):189-202. https://doi.org/10.1016/s0272-6386(99)70131-9

34. Nagao A, Kobayashi M, Koyasu S, Chow CCT, Harada H (2019) HIF-1-dependent reprogramming of glucose metabolic pathway of cancer cells and its therapeutic significance. Int J Mol Sci. https://doi.org/10.3390/ijms20020238

35. Zhang Y, Kurupati R, Liu L, Zhou XY, Zhang G, Hudaihed A, Filisio F, Giles-Davis W, Xu X, Karakousis GC, Schuchter LM, Xu W, Amaravadi R, Xiao M, Sadek N, Krepler C, Herlyn M, Freeman GJ, Rabinowitz JD, Ertl HCJ (2017) Enhancing CD8(+) $\mathrm{T}$ cell fatty acid catabolism within a metabolically challenging tumor microenvironment increases the efficacy of melanoma immunotherapy. Cancer Cell 32(3):377-391 e379. https://doi. org/10.1016/j.ccell.2017.08.004

36. Miska J, Lee-Chang C, Rashidi A, Muroski ME, Chang AL, Lopez-Rosas A, Zhang P, Panek WK, Cordero A, Han Y, Ahmed AU, Chandel NS, Lesniak MS (2019) HIF-1alpha is a metabolic switch between glycolytic-driven migration and oxidative phosphorylation-driven immunosuppression of tregs in glioblastoma. Cell Rep 27(1):226-237 e224. https://doi.org/10.1016/j.celrep. 2019.03.029

37. Michalek RD, Gerriets VA, Jacobs SR, Macintyre AN, MacIver NJ, Mason EF, Sullivan SA, Nichols AG, Rathmell JC (2011) Cutting edge: distinct glycolytic and lipid oxidative metabolic programs are essential for effector and regulatory CD4+ T cell subsets. J Immunol 186(6):3299-3303. https://doi.org/10.4049/ jimmunol.1003613

38. Munn DH, Mellor AL (2007) Indoleamine 2,3-dioxygenase and tumor-induced tolerance. J Clin Invest 117(5):1147-1154. https://doi.org/10.1172/JCI31178

39. Fallarino F, Grohmann U, Vacca C, Bianchi R, Orabona C, Spreca A, Fioretti MC, Puccetti P (2002) T cell apoptosis by tryptophan catabolism. Cell Death Differ 9(10):1069-1077. https://doi.org/10.1038/sj.cdd.4401073

40. Fallarino F, Grohmann U, You S, McGrath BC, Cavener DR, Vacca C, Orabona C, Bianchi R, Belladonna ML, Volpi C, Santamaria P, Fioretti MC, Puccetti P (2006) The combined effects of tryptophan starvation and tryptophan catabolites down-regulate $\mathrm{T}$ cell receptor zeta-chain and induce a regulatory phenotype in naive T cells. J Immunol 176(11):6752-6761. https://doi.org/ 10.4049/jimmunol.176.11.6752

41. Sakaguchi S, Mikami N, Wing JB, Tanaka A, Ichiyama K, Ohkura N (2020) Regulatory T cells and human disease. Annu Rev Immunol 38:541-566. https://doi.org/10.1146/annurevimmunol-042718-041717

42. Nishikawa H, Sakaguchi S (2014) Regulatory T cells in cancer immunotherapy. Curr Opin Immunol 27:1-7. https://doi.org/10. 1016/j.coi.2013.12.005

43. Fridman WH, Pages F, Sautes-Fridman C, Galon J (2012) The immune contexture in human tumours: impact on clinical 
outcome. Nat Rev Cancer 12(4):298-306. https://doi.org/10. 1038/nrc3245

44. Miyara M, Yoshioka Y, Kitoh A, Shima T, Wing K, Niwa A, Parizot C, Taflin C, Heike T, Valeyre D, Mathian A, Nakahata T, Yamaguchi T, Nomura T, Ono M, Amoura Z, Gorochov G, Sakaguchi S (2009) Functional delineation and differentiation dynamics of human CD4+ T cells expressing the FoxP3 transcription factor. Immunity 30(6):899-911. https://doi.org/10. 1016/j.immuni.2009.03.019

45. Saito T, Nishikawa H, Wada H, Nagano Y, Sugiyama D, Atarashi K, Maeda Y, Hamaguchi M, Ohkura N, Sato E, Nagase H, Nishimura J, Yamamoto H, Takiguchi S, Tanoue T, Suda W, Morita H, Hattori M, Honda K, Mori M, Doki Y, Sakaguchi S (2016) Two FOXP3(+)CD4(+) T cell subpopulations distinctly control the prognosis of colorectal cancers. Nat Med 22(6):679684. https://doi.org/10.1038/nm.4086

46. Ohue Y, Nishikawa H (2019) Regulatory T (Treg) cells in cancer: can Treg cells be a new therapeutic target? Cancer Sci 110(7):2080-2089. https://doi.org/10.1111/cas.14069

47. Seo N, Hayakawa S, Takigawa M, Tokura Y (2001) Interleukin-10 expressed at early tumour sites induces subsequent generation of CD4(+) T-regulatory cells and systemic collapse of antitumour immunity. Immunology 103(4):449-457. https:// doi.org/10.1046/j.1365-2567.2001.01279.x

48. Zarek PE, Huang CT, Lutz ER, Kowalski J, Horton MR, Linden J, Drake CG, Powell JD (2008) A2A receptor signaling promotes peripheral tolerance by inducing T-cell anergy and the generation of adaptive regulatory $\mathrm{T}$ cells. Blood 111(1):251259. https://doi.org/10.1182/blood-2007-03-081646

49. Curotto de Lafaille MA, Lafaille JJ (2009) Natural and adaptive foxp3+ regulatory T cells: more of the same or a division of labor? Immunity 30(5):626-635. https://doi.org/10.1016/j. immuni.2009.05.002

50. Zhang Y, Lazarus J, Steele NG, Yan W, Lee HJ, Nwosu ZC, Halbrook CJ, Menjivar RE, Kemp SB, Sirihorachai VR, VelezDelgado A, Donahue K, Carpenter ES, Brown KL, IrizarryNegron V, Nevison AC, Vinta A, Anderson MA, Crawford HC, Lyssiotis CA, Frankel TL, Bednar F, Pasca di Magliano M (2020) Regulatory T-cell depletion alters the tumor microenvironment and accelerates pancreatic carcinogenesis. Cancer Discov 10(3):422-439. https://doi.org/10.1158/2159-8290. CD-19-0958

51. Plitas G, Konopacki C, Wu K, Bos PD, Morrow M, Putintseva EV, Chudakov DM, Rudensky AY (2016) Regulatory t cells exhibit distinct features in human breast cancer. Immunity 45(5):1122-1134. https://doi.org/10.1016/j.immuni.2016.10.032

52. Toor SM, Murshed K, Al-Dhaheri M, Khawar M, Abu Nada M, Elkord E (2019) Immune checkpoints in circulating and tumorinfiltrating $\mathrm{CD} 4(+) \mathrm{T}$ cell subsets in colorectal cancer patients. Front Immunol 10:2936. https://doi.org/10.3389/fimmu.2019. 02936

53. Sanjabi S, Zenewicz LA, Kamanaka M, Flavell RA (2009) Antiinflammatory and pro-inflammatory roles of TGF-beta, IL-10, and IL-22 in immunity and autoimmunity. Curr Opin Pharmacol 9(4):447-453. https://doi.org/10.1016/j.coph.2009.04.008

54. Wrzesinski SH, Wan YY, Flavell RA (2007) Transforming growth factor-beta and the immune response: implications for anticancer therapy. Clin Cancer Res 13(18 Pt 1):5262-5270. https://doi.org/10.1158/1078-0432.CCR-07-1157

55. Mirlekar B, Michaud D, Searcy R, Greene K, Pylayeva-Gupta Y (2018) IL35 hinders endogenous antitumor T-cell immunity and responsiveness to immunotherapy in pancreatic cancer. Cancer Immunol Res 6(9):1014-1024. https://doi.org/10.1158/23266066.CIR-17-0710
56. Takahashi T, Tagami T, Yamazaki S, Uede T, Shimizu J, Sakaguchi N, Mak TW, Sakaguchi S (2000) Immunologic self-tolerance maintained by $\mathrm{CD} 25(+) \mathrm{CD} 4(+)$ regulatory $\mathrm{T}$ cells constitutively expressing cytotoxic T lymphocyte-associated antigen 4. J Exp Med 192(2):303-310. https://doi.org/10.1084/jem.192.2.303

57. Buchbinder EI, Desai A (2016) CTLA-4 and PD-1 pathways: similarities, differences, and implications of their inhibition. Am J Clin Oncol 39(1):98-106. https://doi.org/10.1097/COC.00000 00000000239

58. Huang CT, Workman CJ, Flies D, Pan X, Marson AL, Zhou G, Hipkiss EL, Ravi S, Kowalski J, Levitsky HI, Powell JD, Pardoll DM, Drake CG, Vignali DA (2004) Role of LAG-3 in regulatory T cells. Immunity 21(4):503-513. https://doi.org/10.1016/j. immuni.2004.08.010

59. Campos-Mora M, Morales RA, Gajardo T, Catalan D, PinoLagos K (2013) Neuropilin-1 in transplantation tolerance. Front Immunol 4:405. https://doi.org/10.3389/fimmu.2013.00405

60. Chaudhary B, Khaled YS, Ammori BJ, Elkord E (2014) Neuropilin 1: function and therapeutic potential in cancer. Cancer Immunol Immunother 63(2):81-99. https://doi.org/10.1007/ s00262-013-1500-0

61. Cao X, Cai SF, Fehniger TA, Song J, Collins LI, Piwnica-Worms DR, Ley TJ (2007) Granzyme B and perforin are important for regulatory $\mathrm{T}$ cell-mediated suppression of tumor clearance. Immunity 27(4):635-646. https://doi.org/10.1016/j.immuni. 2007.08.014

62. Facciabene A, Motz GT, Coukos G (2012) T-regulatory cells: key players in tumor immune escape and angiogenesis. Cancer Res 72(9):2162-2171. https://doi.org/10.1158/0008-5472. CAN-11-3687

63. Katsuno Y, Lamouille S, Derynck R (2013) TGF-beta signaling and epithelial-mesenchymal transition in cancer progression. Curr Opin Oncol 25(1):76-84. https://doi.org/10.1097/CCO. 0b013e32835b6371

64. Nickerson NK, Mill CP, Wu HJ, Riese DJ 2nd, Foley J (2013) Autocrine-derived epidermal growth factor receptor ligands contribute to recruitment of tumor-associated macrophage and growth of basal breast cancer cells in vivo. Oncol Res 20(7):303317. https://doi.org/10.3727/096504013x13639794277761

65. Paluskievicz CM, Cao X, Abdi R, Zheng P, Liu Y, Bromberg JS (2019) T regulatory cells and priming the suppressive tumor microenvironment. Front Immunol 10:2453. https://doi.org/10. 3389/fimmu.2019.02453

66. Gupta S, Joshi K, Wig JD, Arora SK (2007) Intratumoral FOXP3 expression in infiltrating breast carcinoma: its association with clinicopathologic parameters and angiogenesis. Acta Oncol 46(6):792-797. https://doi.org/10.1080/02841860701233443

67. Shimizu J, Yamazaki S, Sakaguchi S (1999) Induction of tumor immunity by removing CD25+CD4+ T cells: a common basis between tumor immunity and autoimmunity. J Immunol 163(10):5211-5218

68. Shi C, Chen Y, Chen Y, Yang Y, Bing W, Qi J (2019) CD4(+) $\mathrm{CD} 25(+)$ regulatory $\mathrm{T}$ cells promote hepatocellular carcinoma invasion via TGF-beta1-induced epithelial-mesenchymal transition. Onco Targets Ther 12:279-289. https://doi.org/10.2147/ OTT.S 172417

69. Angelin A, Gil-de-Gomez L, Dahiya S, Jiao J, Guo L, Levine MH, Wang Z, Quinn WJ, 3rd, Kopinski PK, Wang L, Akimova T, Liu Y, Bhatti TR, Han R, Laskin BL, Baur JA, Blair IA, Wallace DC, Hancock WW, Beier UH (2017) Foxp3 reprograms T cell metabolism to function in low-glucose, high-lactate environments. Cell Metab 25(6):1282-1293 e1287. https://doi.org/10. 1016/j.cmet.2016.12.018

70. Kishore M, Cheung KCP, Fu H, Bonacina F, Wang G, Coe D, Ward EJ, Colamatteo A, Jangani M, Baragetti A, Matarese G, 
Smith DM, Haas R, Mauro C, Wraith DC, Okkenhaug K, Catapano AL, De Rosa V, Norata GD, Marelli-Berg FM (2017) Regulatory $\mathrm{T}$ cell migration is dependent on glucokinase-mediated glycolysis. Immunity 47(5):875-889 e810. https://doi.org/10. 1016/j.immuni.2017.10.017

71. Jordan JT, Sun W, Hussain SF, DeAngulo G, Prabhu SS, Heimberger AB (2008) Preferential migration of regulatory T cells mediated by glioma-secreted chemokines can be blocked with chemotherapy. Cancer Immunol Immunother 57(1):123-131. https://doi.org/10.1007/s00262-007-0336-x

72. Brandacher G, Perathoner A, Ladurner R, Schneeberger S, Obrist P, Winkler C, Werner ER, Werner-Felmayer G, Weiss HG, Gobel G, Margreiter R, Konigsrainer A, Fuchs D, Amberger A (2006) Prognostic value of indoleamine 2,3-dioxygenase expression in colorectal cancer: effect on tumor-infiltrating T cells. Clin Cancer Res 12(4):1144-1151. https://doi.org/10.1158/1078-0432. CCR-05-1966

73. Ino K, Yamamoto E, Shibata K, Kajiyama H, Yoshida N, Terauchi M, Nawa A, Nagasaka T, Takikawa O, Kikkawa F (2008) Inverse correlation between tumoral indoleamine 2,3-dioxygenase expression and tumor-infiltrating lymphocytes in endometrial cancer: its association with disease progression and survival. Clin Cancer Res 14(8):2310-2317. https://doi.org/ 10.1158/1078-0432.CCR-07-4144

74. Nakamura T, Shima T, Saeki A, Hidaka T, Nakashima A, Takikawa O, Saito S (2007) Expression of indoleamine 2, 3-dioxygenase and the recruitment of Foxp3-expressing regulatory $\mathrm{T}$ cells in the development and progression of uterine cervical cancer. Cancer Sci 98(6):874-881. https://doi.org/10.1111/j.1349-7006. 2007.00470.x

75. Folgiero V, Miele E, Carai A, Ferretti E, Alfano V, Po A, Bertaina V, Goffredo BM, Benedetti MC, Camassei FD, Cacchione A, Locatelli F, Mastronuzzi A (2016) IDO1 involvement in mTOR pathway: a molecular mechanism of resistance to mTOR targeting in medulloblastoma. Oncotarget 7(33):52900-52911. https://doi.org/10.18632/oncotarget.9284

76. Pacella I, Procaccini C, Focaccetti C, Miacci S, Timperi E, Faicchia D, Severa M, Rizzo F, Coccia EM, Bonacina F, Mitro N, Norata GD, Rossetti G, Ranzani V, Pagani M, Giorda E, Wei Y, Matarese G, Barnaba V, Piconese S (2018) Fatty acid metabolism complements glycolysis in the selective regulatory $\mathrm{T}$ cell expansion during tumor growth. Proc Natl Acad Sci U S A 115(28):E6546-e6555. https://doi.org/10.1073/pnas.1720113115

77. Li L, Liu X, Sanders KL, Edwards JL, Ye J, Si F, Gao A, Huang L, Hsueh EC, Ford DA, Hoft DF, Peng G (2019) TLR8-mediated metabolic control of human treg function: a mechanistic target for cancer immunotherapy. Cell Metab 29(1):103-123 e105. https://doi.org/10.1016/j.cmet.2018.09.020

78. Sun IH, Oh MH, Zhao L, Patel CH, Arwood ML, Xu W, Tam AJ, Blosser RL, Wen J, Powell JD (2018) mTOR complex 1 signaling regulates the generation and function of central and effector Foxp3(+) regulatory T Cells. J Immunol 201(2):481-492. https:// doi.org/10.4049/jimmunol.1701477

79. Lowe MM, Boothby I, Clancy S, Ahn RS, Liao W, Nguyen DN, Schumann K, Marson A, Mahuron KM, Kingsbury GA, Liu Z, Munoz Sandoval P, Rodriguez RS, Pauli ML, Taravati K, Arron ST, Neuhaus IM, Harris HW, Kim EA, Shin US, Krummel MF, Daud A, Scharschmidt TC, Rosenblum MD (2019) Regulatory T cells use arginase 2 to enhance their metabolic fitness in tissues. JCI Insight. https://doi.org/10.1172/jci.insight.129756

80. Maj T, Wang W, Crespo J, Zhang H, Wang W, Wei S, Zhao L, Vatan L, Shao I, Szeliga W, Lyssiotis C, Liu JR, Kryczek I, Zou W (2017) Oxidative stress controls regulatory T cell apoptosis and suppressor activity and PD-L1-blockade resistance in tumor. Nat Immunol 18(12):1332-1341. https://doi.org/10.1038/ni.3868
81. Field CS, Baixauli F, Kyle RL, Puleston DJ, Cameron AM, Sanin DE, Hippen KL, Loschi M, Thangavelu G, Corrado M, EdwardsHicks J, Grzes KM, Pearce EJ, Blazar BR, Pearce EL (2020) Mitochondrial integrity regulated by lipid metabolism is a cellintrinsic checkpoint for treg suppressive function. Cell Metab 31(2):422-437 e425. https://doi.org/10.1016/j.cmet.2019.11.021

82. Weinberg SE, Singer BD, Steinert EM, Martinez CA, Mehta MM, Martinez-Reyes I, Gao P, Helmin KA, Abdala-Valencia H, Sena LA, Schumacker PT, Turka LA, Chandel NS (2019) Mitochondrial complex III is essential for suppressive function of regulatory T cells. Nature 565(7740):495-499. https://doi.org/ 10.1038/s41586-018-0846-Z

83. Chang WH, Lai AG (2019) The pan-cancer mutational landscape of the PPAR pathway reveals universal patterns of dysregulated metabolism and interactions with tumor immunity and hypoxia. Ann N Y Acad Sci 1448(1):65-82. https://doi.org/10.1111/nyas. 14170

84. Muroski ME, Miska J, Chang AL, Zhang P, Rashidi A, Moore H, Lopez-Rosas A, Han Y, Lesniak MS (2017) Fatty acid uptake in $\mathrm{T}$ cell subsets using a quantum dot fatty acid conjugate. Sci Rep 7(1):5790. https://doi.org/10.1038/s41598-017-05556-x

85. Delgoffe GM, Woo SR, Turnis ME, Gravano DM, Guy C, Overacre AE, Bettini ML, Vogel P, Finkelstein D, Bonnevier J, Workman CJ, Vignali DA (2013) Stability and function of regulatory T cells is maintained by a neuropilin-1-semaphorin-4a axis. Nature 501(7466):252-256. https://doi.org/10.1038/nature12428

86. Magnuson AM, Kiner E, Ergun A, Park JS, Asinovski N, OrtizLopez A, Kilcoyne A, Paoluzzi-Tomada E, Weissleder R, Mathis D, Benoist C (2018) Identification and validation of a tumor-infiltrating Treg transcriptional signature conserved across species and tumor types. Proc Natl Acad Sci U S A 115(45):E10672E10681. https://doi.org/10.1073/pnas.1810580115

87. Chapman NM, Zeng H, Nguyen TM, Wang Y, Vogel P, Dhungana Y, Liu X, Neale G, Locasale JW, Chi H (2018) mTOR coordinates transcriptional programs and mitochondrial metabolism of activated Treg subsets to protect tissue homeostasis. Nat Commun 9(1):2095. https://doi.org/10.1038/s41467-018-04392-5

88. Donninelli G, Del Corno M, Pierdominici M, Scazzocchio B, Vari R, Varano B, Pacella I, Piconese S, Barnaba V, D'Archivio M, Masella R, Conti L, Gessani S (2017) Distinct blood and visceral adipose tissue regulatory $\mathrm{T}$ cell and innate lymphocyte profiles characterize obesity and colorectal cancer. Front Immunol 8:643. https://doi.org/10.3389/fimmu.2017.00643

89. Raychaudhuri D, Bhattacharya R, Sinha BP, Liu CSC, Ghosh AR, Rahaman O, Bandopadhyay P, Sarif J, D'Rozario R, Paul S, Das A, Sarkar DK, Chattopadhyay S, Ganguly D (2019) Lactate induces pro-tumor reprogramming in intratumoral plasmacytoid dendritic cells. Front Immunol 10:1878. https://doi.org/10.3389/ fimmu.2019.01878

90. Kryczek I, Wu K, Zhao E, Wei S, Vatan L, Szeliga W, Huang E, Greenson J, Chang A, Rolinski J, Radwan P, Fang J, Wang G, Zou W (2011) IL-17+ regulatory T cells in the microenvironments of chronic inflammation and cancer. J Immunol 186(7):4388-4395. https://doi.org/10.4049/jimmunol.1003251

91. Rizzo A, Di Giovangiulio M, Stolfi C, Franze E, Fehling HJ, Carsetti R, Giorda E, Colantoni A, Ortenzi A, Rugge M, Mescoli C, Monteleone G, Fantini MC (2018) RORgammatexpressing tregs drive the growth of colitis-associated colorectal cancer by controlling IL6 in dendritic cells. Cancer Immunol Res 6(9):1082-1092. https://doi.org/10.1158/2326-6066. CIR-17-0698

92. Jetten AM, Takeda Y, Slominski A, Kang HS (2018) Retinoic acid-related orphan receptor gamma (RORgamma): connecting sterol metabolism to regulation of the immune system and autoimmune disease. Curr Opin Toxicol 8:66-80. https://doi.org/10. 1016/j.cotox.2018.01.005 
93. Pan Y, Tian T, Park CO, Lofftus SY, Mei S, Liu X, Luo C, O’Malley JT, Gehad A, Teague JE, Divito SJ, Fuhlbrigge R, Puigserver P, Krueger JG, Hotamisligil GS, Clark RA, Kupper TS (2017) Survival of tissue-resident memory T cells requires exogenous lipid uptake and metabolism. Nature 543(7644):252256. https://doi.org/10.1038/nature21379

94. Kabelitz D, Wesch D, He W (2007) Perspectives of gammadelta T cells in tumor immunology. Cancer Res 67(1):5-8. https://doi. org/10.1158/0008-5472.CAN-06-3069

95. Peng G, Wang HY, Peng W, Kiniwa Y, Seo KH, Wang RF (2007) Tumor-infiltrating gammadelta $\mathrm{T}$ cells suppress $\mathrm{T}$ and dendritic cell function via mechanisms controlled by a unique toll-like receptor signaling pathway. Immunity $27(2): 334-348$. https:// doi.org/10.1016/j.immuni.2007.05.020

96. Wesch D, Peters C, Siegers GM (2014) Human gamma delta T regulatory cells in cancer: fact or fiction? Front Immunol 5:598. https://doi.org/10.3389/fimmu.2014.00598

97. Kang N, Tang L, Li X, Wu D, Li W, Chen X, Cui L, Ba D, He W (2009) Identification and characterization of Foxp3(+) gammadelta T cells in mouse and human. Immunol Lett 125(2):105113. https://doi.org/10.1016/j.imlet.2009.06.005

98. Ma C, Zhang Q, Ye J, Wang F, Zhang Y, Wevers E, Schwartz T, Hunborg P, Varvares MA, Hoft DF, Hsueh EC, Peng G (2012) Tumor-infiltrating gammadelta $\mathrm{T}$ lymphocytes predict clinical outcome in human breast cancer. J Immunol 189(10):50295036. https://doi.org/10.4049/jimmunol.1201892

99. Gober HJ, Kistowska M, Angman L, Jeno P, Mori L, De Libero G (2003) Human T cell receptor gammadelta cells recognize endogenous mevalonate metabolites in tumor cells. J Exp Med 197(2):163-168. https://doi.org/10.1084/jem.20021500

100. Raverdeau M, Cunningham SP, Harmon C, Lynch L (2019) gammadelta $T$ cells in cancer: a small population of lymphocytes with big implications. Clin Transl Immunol 8(10):e01080. https://doi.org/10.1002/cti2.1080

101. Wang H, Henry O, Distefano MD, Wang YC, Raikkonen J, Monkkonen J, Tanaka Y, Morita CT (2013) Butyrophilin 3A1 plays an essential role in prenyl pyrophosphate stimulation of human Vgamma2Vdelta2 T cells. J Immunol 191(3):10291042. https://doi.org/10.4049/jimmunol.1300658

102. Casetti R, Agrati C, Wallace M, Sacchi A, Martini F, Martino A, Rinaldi A, Malkovsky M (2009) Cutting edge: TGF-beta1 and IL-15 Induce FOXP3+ gammadelta regulatory T cells in the presence of antigen stimulation. J Immunol 183(6):35743577. https://doi.org/10.4049/jimmunol.0901334

103. Schreiber TH, Wolf D, Bodero M, Podack E (2012) Tumor antigen specific iTreg accumulate in the tumor microenvironment and suppress therapeutic vaccination. Oncoimmunology 1(5):642-648. https://doi.org/10.4161/onci.20298

104. Zhou G, Drake CG, Levitsky HI (2006) Amplification of tumor-specific regulatory $\mathrm{T}$ cells following therapeutic cancer vaccines. Blood 107(2):628-636. https://doi.org/10.1182/ blood-2005-07-2737

105. Clambey ET, McNamee EN, Westrich JA, Glover LE, Campbell EL, Jedlicka P, de Zoeten EF, Cambier JC, Stenmark KR, Colgan SP, Eltzschig HK (2012) Hypoxia-inducible factor-1 alpha-dependent induction of FoxP3 drives regulatory T-cell abundance and function during inflammatory hypoxia of the mucosa. Proc Natl Acad Sci U S A 109(41):E2784-2793. https://doi.org/10.1073/pnas.1202366109

106. Fong GH, Takeda K (2008) Role and regulation of prolyl hydroxylase domain proteins. Cell Death Differ 15(4):635641. https://doi.org/10.1038/cdd.2008.10

107. Deng B, Zhu JM, Wang Y, Liu TT, Ding YB, Xiao WM, Lu GT, Bo P, Shen XZ (2013) Intratumor hypoxia promotes immune tolerance by inducing regulatory $\mathrm{T}$ cells via TGF-beta1 in gastric cancer. PLoS ONE 8(5):e63777. https://doi.org/10. 1371/journal.pone.0063777

108. Chen J, Jiang CC, Jin L, Zhang XD (2016) Regulation of PD-L1: a novel role of pro-survival signalling in cancer. Ann Oncol 27(3):409-416. https://doi.org/10.1093/annonc/mdv615

109. Ruf M, Moch H, Schraml P (2016) PD-L1 expression is regulated by hypoxia inducible factor in clear cell renal cell carcinoma. Int J Cancer 139(2):396-403. https://doi.org/10.1002/ijc.30077

110. Szajnik M, Czystowska M, Szczepanski MJ, Mandapathil M, Whiteside TL (2010) Tumor-derived microvesicles induce, expand and up-regulate biological activities of human regulatory T cells (Treg). PLoS ONE 5(7):e11469. https://doi.org/10. 1371/journal.pone.0011469

111. Yin Y, Cai X, Chen X, Liang H, Zhang Y, Li J, Wang Z, Chen X, Zhang W, Yokoyama S, Wang C, Li L, Li L, Hou D, Dong L, Xu T, Hiroi T, Yang F, Ji H, Zhang J, Zen K, Zhang CY (2014) Tumor-secreted miR-214 induces regulatory T cells: a major link between immune evasion and tumor growth. Cell Res 24(10):1164-1180. https://doi.org/10.1038/cr.2014.121

112. Brennan P, Babbage JW, Burgering BM, Groner B, Reif K, Cantrell DA (1997) Phosphatidylinositol 3-kinase couples the interleukin-2 receptor to the cell cycle regulator E2F. Immunity 7(5):679-689. https://doi.org/10.1016/s1074-7613(00)80388-X

113. Huynh A, DuPage M, Priyadharshini B, Sage PT, Quiros J, Borges CM, Townamchai N, Gerriets VA, Rathmell JC, Sharpe AH, Bluestone JA, Turka LA (2015) Control of PI(3) kinase in Treg cells maintains homeostasis and lineage stability. Nat Immunol 16(2):188-196. https://doi.org/10.1038/ni.3077

114. Haxhinasto S, Mathis D, Benoist C (2008) The AKT-mTOR axis regulates de novo differentiation of CD4+Foxp3+ cells. J Exp Med 205(3):565-574. https://doi.org/10.1084/jem.20071477

115. Shi LZ, Wang R, Huang G, Vogel P, Neale G, Green DR, Chi H (2011) HIF1alpha-dependent glycolytic pathway orchestrates a metabolic checkpoint for the differentiation of TH17 and Treg cells. J Exp Med 208(7):1367-1376. https://doi.org/10.1084/jem. 20110278

116. Berod L, Friedrich C, Nandan A, Freitag J, Hagemann S, Harmrolfs K, Sandouk A, Hesse C, Castro CN, Bahre H, Tschirner SK, Gorinski N, Gohmert M, Mayer CT, Huehn J, Ponimaskin E, Abraham WR, Muller R, Lochner M, Sparwasser T (2014) De novo fatty acid synthesis controls the fate between regulatory $\mathrm{T}$ and T helper 17 cells. Nat Med 20(11):1327-1333. https://doi. org/10.1038/nm.3704

117. Svensson RU, Parker SJ, Eichner LJ, Kolar MJ, Wallace M, Brun SN, Lombardo PS, Van Nostrand JL, Hutchins A, Vera L, Gerken L, Greenwood J, Bhat S, Harriman G, Westlin WF, Harwood HJ Jr, Saghatelian A, Kapeller R, Metallo CM, Shaw RJ (2016) Inhibition of acetyl-CoA carboxylase suppresses fatty acid synthesis and tumor growth of non-small-cell lung cancer in preclinical models. Nat Med 22(10):1108-1119. https://doi.org/10.1038/nm. 4181

118. Gerriets VA, Kishton RJ, Johnson MO, Cohen S, Siska PJ, Nichols AG, Warmoes MO, de Cubas AA, MacIver NJ, Locasale JW, Turka LA, Wells AD, Rathmell JC (2016) Foxp3 and Toll-like receptor signaling balance Treg cell anabolic metabolism for suppression. Nat Immunol 17(12):1459-1466. https://doi.org/ 10.1038/ni.3577

119. Procaccini C, De Rosa V, Galgani M, Abanni L, Cali G, Porcellini A, Carbone F, Fontana S, Horvath TL, La Cava A, Matarese $\mathrm{G}$ (2010) An oscillatory switch in mTOR kinase activity sets regulatory T cell responsiveness. Immunity 33(6):929-941. https://doi.org/10.1016/j.immuni.2010.11.024

120. Hosomi K, Kunisawa J (2017) The specific roles of vitamins in the regulation of immunosurveillance and maintenance of immunologic homeostasis in the gut. Immune Netw 17(1):13-19. https://doi.org/10.4110/in.2017.17.1.13 
121. Lu L, Lan Q, Li Z, Zhou X, Gu J, Li Q, Wang J, Chen M, Liu Y, Shen Y, Brand DD, Ryffel B, Horwitz DA, Quismorio FP, Liu Z, Li B, Olsen NJ, Zheng SG (2014) Critical role of alltrans retinoic acid in stabilizing human natural regulatory $\mathrm{T}$ cells under inflammatory conditions. Proc Natl Acad Sci U S A 111(33):E3432-3440. https://doi.org/10.1073/pnas.1408780111

122. Lu L, Ma J, Li Z, Lan Q, Chen M, Liu Y, Xia Z, Wang J, Han Y, Shi W, Quesniaux V, Ryffel B, Brand D, Li B, Liu Z, Zheng SG (2011) All-trans retinoic acid promotes TGF- $\beta$-induced Tregs via histone modification but not DNA demethylation on Foxp3 gene locus. PLoS ONE 6(9):e24590. https://doi.org/10.1371/journal. pone. 0024590

123. Mucida D, Park Y, Kim G, Turovskaya O, Scott I, Kronenberg M, Cheroutre H (2007) Reciprocal TH17 and regulatory T cell differentiation mediated by retinoic acid. Sci NY 317(5835):256260. https://doi.org/10.1126/science.1145697

124. Zheng SG, Wang J, Wang P, Gray JD, Horwitz DA (2007) IL-2 is essential for TGF-beta to convert naive CD4+CD25- cells to CD25+Foxp3+ regulatory $\mathrm{T}$ cells and for expansion of these cells. J Immunol 178(4):2018-2027. https://doi.org/10.4049/ jimmunol.178.4.2018

125. Hill JA, Hall JA, Sun CM, Cai Q, Ghyselinck N, Chambon P, Belkaid Y, Mathis D, Benoist C (2008) Retinoic acid enhances Foxp3 induction indirectly by relieving inhibition from CD4+CD44hi Cells. Immunity 29(5):758-770. https://doi.org/ 10.1016/j.immuni.2008.09.018

126. Yue X, Trifari S, Äijö T, Tsagaratou A, Pastor WA, ZepedaMartínez JA, Lio CW, Li X, Huang Y, Vijayanand P, Lähdesmäki H, Rao A (2016) Control of Foxp3 stability through modulation of TET activity. J Exp Med 213(3):377-397. https://doi.org/10. 1084/jem.20151438

127. Sasidharan Nair V, Song MH, Oh KI (2016) Vitamin C facilitates demethylation of the Foxp3 enhancer in a Tet-dependent manner. J Immunol 196(5):2119-2131. https://doi.org/10.4049/jimmunol. 1502352

128. Rasmussen KD, Helin K (2016) Role of TET enzymes in DNA methylation, development, and cancer. Genes Dev 30(7):733750. https://doi.org/10.1101/gad.276568.115

129. Yue X, Lio CJ, Samaniego-Castruita D, Li X, Rao A (2019) Loss of TET2 and TET3 in regulatory T cells unleashes effector function. Nat Commun 10(1):2011. https://doi.org/10.1038/ s41467-019-09541-y

130. Nikolouli E, Hardtke-Wolenski M, Hapke M, Beckstette M, Geffers R, Floess S, Jaeckel E, Huehn J (2017) Alloantigen-induced regulatory $\mathrm{T}$ cells generated in presence of vitamin $\mathrm{C}$ display enhanced stability of Foxp3 expression and promote skin allograft acceptance. Front Immunol 8:748. https://doi.org/10.3389/ fimmu.2017.00748

131. Jeffery LE, Burke F, Mura M, Zheng Y, Qureshi OS, Hewison M, Walker LS, Lammas DA, Raza K, Sansom DM (2009) 1,25-Dihydroxyvitamin D3 and IL-2 combine to inhibit T cell production of inflammatory cytokines and promote development of regulatory T cells expressing CTLA-4 and FoxP3. J Immunol 183(9):5458-5467. https://doi.org/10.4049/jimmunol.0803217

132. Joshi S, Pantalena LC, Liu XK, Gaffen SL, Liu H, RohowskyKochan C, Ichiyama K, Yoshimura A, Steinman L, Christakos S, Youssef S (2011) 1,25-dihydroxyvitamin D(3) ameliorates Th17 autoimmunity via transcriptional modulation of interleukin-17A. Mol Cell Biol 31(17):3653-3669. https://doi.org/10.1128/mcb. 05020-11

133. Kang SW, Kim SH, Lee N, Lee WW, Hwang KA, Shin MS, Lee SH, Kim WU, Kang I (2012) 1,25-Dihyroxyvitamin D3 promotes FOXP3 expression via binding to vitamin D response elements in its conserved noncoding sequence region. J Immunol 188(11):5276-5282. https://doi.org/10.4049/jimmunol.1101211
134. Fisher SA, Rahimzadeh M, Brierley C, Gration B, Doree C, Kimber CE, Plaza Cajide A, Lamikanra AA, Roberts DJ (2019) The role of vitamin $\mathrm{D}$ in increasing circulating $\mathrm{T}$ regulatory cell numbers and modulating $T$ regulatory cell phenotypes in patients with inflammatory disease or in healthy volunteers: a systematic review. PLoS ONE 14(9):e0222313. https://doi.org/10.1371/ journal.pone. 0222313

135. Singh N, Gurav A, Sivaprakasam S, Brady E, Padia R, Shi H, Thangaraju M, Prasad PD, Manicassamy S, Munn DH, Lee JR, Offermanns S, Ganapathy V (2014) Activation of Gpr109a, receptor for niacin and the commensal metabolite butyrate, suppresses colonic inflammation and carcinogenesis. Immunity 40(1):128-139. https://doi.org/10.1016/j.immuni.2013.12.007

136. Hegyi J, Schwartz RA, Hegyi V (2004) Pellagra: dermatitis, dementia, and diarrhea. Int J Dermatol 43(1):1-5. https://doi. org/10.1111/j.1365-4632.2004.01959.x

137. Moretti S, Menicali E, Voce P, Morelli S, Cantarelli S, Sponziello M, Colella R, Fallarino F, Orabona C, Alunno A, de Biase D, Bini V, Mameli MG, Filetti S, Gerli R, Macchiarulo A, Melillo RM, Tallini G, Santoro M, Puccetti P, Avenia N, Puxeddu E (2014) Indoleamine 2,3-dioxygenase 1 (IDO1) is up-regulated in thyroid carcinoma and drives the development of an immunosuppressant tumor microenvironment. J Clin Endocrinol Metabol 99(5):E832-840. https://doi.org/10.1210/jc.2013-3351

138. Baban B, Chandler PR, Sharma MD, Pihkala J, Koni PA, Munn DH, Mellor AL (2009) IDO activates regulatory T cells and blocks their conversion into Th17-like T cells. J Immunol 183(4):2475-2483. https://doi.org/10.4049/jimmunol.0900986

139. Sharma MD, Hou DY, Liu Y, Koni PA, Metz R, Chandler P, Mellor AL, He Y, Munn DH (2009) Indoleamine 2,3-dioxygenase controls conversion of Foxp3+ Tregs to TH17-like cells in tumor-draining lymph nodes. Blood 113(24):6102-6111. https:// doi.org/10.1182/blood-2008-12-195354

140. Sharma MD, Baban B, Chandler P, Hou DY, Singh N, Yagita H, Azuma M, Blazar BR, Mellor AL, Munn DH (2007) Plasmacytoid dendritic cells from mouse tumor-draining lymph nodes directly activate mature Tregs via indoleamine 2,3-dioxygenase. J Clin Invest 117(9):2570-2582. https://doi.org/10.1172/jci31911

141. Opitz CA, Litzenburger UM, Sahm F, Ott M, Tritschler I, Trump S, Schumacher T, Jestaedt L, Schrenk D, Weller M, Jugold M, Guillemin GJ, Miller CL, Lutz C, Radlwimmer B, Lehmann I, von Deimling A, Wick W, Platten M (2011) An endogenous tumour-promoting ligand of the human aryl hydrocarbon receptor. Nature 478(7368):197-203. https://doi.org/10.1038/natur e10491

142. Nguyen NT, Kimura A, Nakahama T, Chinen I, Masuda K, Nohara K, Fujii-Kuriyama Y, Kishimoto T (2010) Aryl hydrocarbon receptor negatively regulates dendritic cell immunogenicity via a kynurenine-dependent mechanism. Proc Natl Acad Sci U S A 107(46):19961-19966. https://doi.org/10.1073/pnas.10144 65107

143. Munn DH, Sharma MD, Baban B, Harding HP, Zhang Y, Ron D, Mellor AL (2005) GCN2 kinase in T cells mediates proliferative arrest and anergy induction in response to indoleamine 2,3-dioxygenase. Immunity 22(5):633-642. https://doi.org/10. 1016/j.immuni.2005.03.013

144. Sharma MD, Shinde R, McGaha TL, Huang L, Holmgaard RB, Wolchok JD, Mautino MR, Celis E, Sharpe AH, Francisco LM, Powell JD, Yagita H, Mellor AL, Blazar BR, Munn DH (2015) The PTEN pathway in Tregs is a critical driver of the suppressive tumor microenvironment. Sci Adv 1(10):e1500845. https://doi. org/10.1126/sciadv. 1500845

145. Schenk U, Frascoli M, Proietti M, Geffers R, Traggiai E, Buer J, Ricordi C, Westendorf AM, Grassi F (2011) ATP inhibits the generation and function of regulatory $\mathrm{T}$ cells through the 
activation of purinergic P2X receptors. Sci Signal 4(162):ra12. https://doi.org/10.1126/scisignal.2001270

146. Borsellino G, Kleinewietfeld M, Di Mitri D, Sternjak A, Diamantini A, Giometto R, Höpner S, Centonze D, Bernardi G, Dell'Acqua ML, Rossini PM, Battistini L, Rötzschke O, Falk K (2007) Expression of ectonucleotidase CD39 by Foxp3+ Treg cells: hydrolysis of extracellular ATP and immune suppression. Blood 110(4):1225-1232. https://doi.org/10.1182/ blood-2006-12-064527

147. Saleh R, Elkord E (2020) FoxP3(+) T regulatory cells in cancer: Prognostic biomarkers and therapeutic targets. Cancer Lett 490:174-185. https://doi.org/10.1016/j.canlet.2020.07.022

148. Deaglio S, Dwyer KM, Gao W, Friedman D, Usheva A, Erat A, Chen JF, Enjyoji K, Linden J, Oukka M, Kuchroo VK, Strom TB, Robson SC (2007) Adenosine generation catalyzed by CD39 and CD73 expressed on regulatory T cells mediates immune suppression. J Exp Med 204(6):1257-1265. https://doi.org/10.1084/jem. 20062512

149. Saleh R, Elkord E (2019) Treg-mediated acquired resistance to immune checkpoint inhibitors. Cancer Lett 457:168-179. https:// doi.org/10.1016/j.canlet.2019.05.003

150. Li JY, Duan XF, Wang LP, Xu YJ, Huang L, Zhang TF, Liu JY, Li F, Zhang Z, Yue DL, Wang F, Zhang B, Zhang Y (2014) Selective depletion of regulatory $\mathrm{T}$ cell subsets by docetaxel treatment in patients with nonsmall cell lung cancer. J Immunol Res 2014:286170. https://doi.org/10.1155/2014/286170

151. Lissoni P, Brivio F, Fumagalli L, Messina G, Meregalli S, Porro G, Rovelli F, Vigorè L, Tisi E, D’Amico G (2009) Effects of the conventional antitumor therapies surgery, chemotherapy, radiotherapy and immunotherapy on regulatory $\mathrm{T}$ lymphocytes in cancer patients. Anticancer Res 29(5):1847-1852

152. Verma A, Mathur R, Farooque A, Kaul V, Gupta S, Dwarakanath BS (2019) T-regulatory cells in tumor progression and therapy. Cancer Manag Res 11:10731-10747. https://doi.org/10.2147/ CMAR.S228887

153. Cao M, Cabrera R, Xu Y, Liu C, Nelson D (2009) Gamma irradiation alters the phenotype and function of CD4+CD25+ regulatory T cells. Cell Biol Int 33(5):565-571. https://doi.org/10. 1016/j.cellbi.2009.02.007

154. Greten TF, Ormandy LA, Fikuart A, Höchst B, Henschen S, Hörning M, Manns MP, Korangy F (2010) Low-dose cyclophosphamide treatment impairs regulatory T cells and unmasks AFPspecific CD4+ T-cell responses in patients with advanced HCC. J Immunother (Hagerstown, Md : 1997) 33(2):211-218. https:// doi.org/10.1097/CJI.0b013e3181bb499f

155. Generali D, Bates G, Berruti A, Brizzi MP, Campo L, Bonardi S, Bersiga A, Allevi G, Milani M, Aguggini S, Dogliotti L, Banham AH, Harris AL, Bottini A, Fox SB (2009) Immunomodulation of FOXP3+ regulatory $\mathrm{T}$ cells by the aromatase inhibitor letrozole in breast cancer patients. Clin Cancer Res 15(3):1046-1051. https://doi.org/10.1158/1078-0432.ccr-08-1507

156. Kareva I (2019) Metabolism and gut microbiota in cancer immunoediting, CD8/Treg ratios, immune cell homeostasis, and cancer (immuno)therapy: concise review. Stem Cells 37(10):1273-1280. https://doi.org/10.1002/stem.3051

157. Patel MA, Kim JE, Theodros D, Tam A, Velarde E, Kochel CM, Francica B, Nirschl TR, Ghasemzadeh A, Mathios D, HarrisBookman S, Jackson CC, Jackson C, Ye X, Tran PT, Tyler B, Coric V, Selby M, Brem H, Drake CG, Pardoll DM, Lim M (2016) Agonist anti-GITR monoclonal antibody and stereotactic radiation induce immune-mediated survival advantage in murine intracranial glioma. J Immunother Cancer 4:28. https://doi.org/ 10.1186/s40425-016-0132-2

158. Muroyama Y, Nirschl TR, Kochel CM, Lopez-Bujanda Z, Theodros D, Mao W, Carrera-Haro MA, Ghasemzadeh A, Marciscano AE, Velarde E, Tam AJ, Thoburn CJ, Uddin M, Meeker
AK, Anders RA, Pardoll DM, Drake CG (2017) Stereotactic radiotherapy increases functionally suppressive regulatory $\mathrm{T}$ cells in the tumor microenvironment. Cancer Immunol Res 5(11):992-1004. https://doi.org/10.1158/2326-6066.cir-17-0040

159. Schuler PJ, Harasymczuk M, Schilling B, Saze Z, Strauss L, Lang S, Johnson JT, Whiteside TL (2013) Effects of adjuvant chemoradiotherapy on the frequency and function of regulatory $\mathrm{T}$ cells in patients with head and neck cancer. Clin Cancer Res 19(23):6585-6596. https://doi.org/10.1158/1078-0432. CCR-13-0900

160. Oweida A, Darragh L, Bhatia S, Raben D, Heasley L, Nemenoff R, Clambey E, Karam S (2019) Regulatory T cells mediate resistance to radiotherapy in head and neck squamous cell carcinoma. J Clin Oncol 37(8_suppl):70-70. https://doi.org/10.1200/JCO. 2019.37.8_suppl.70

161. Crellin NK, Garcia RV, Levings MK (2007) Altered activation of AKT is required for the suppressive function of human CD4+CD25+ T regulatory cells. Blood 109(5):2014-2022. https://doi.org/10.1182/blood-2006-07-035279

162. Sauer S, Bruno L, Hertweck A, Finlay D, Leleu M, Spivakov M, Knight ZA, Cobb BS, Cantrell D, O'Connor E, Shokat KM, Fisher AG, Merkenschlager M (2008) T cell receptor signaling controls Foxp3 expression via PI3K, Akt, and mTOR. Proc Natl Acad Sci U S A 105(22):7797-7802. https://doi.org/10.1073/ pnas.0800928105

163. Zeng H, Yang K, Cloer C, Neale G, Vogel P, Chi H (2013) mTORC1 couples immune signals and metabolic programming to establish T(reg)-cell function. Nature 499(7459):485-490. https://doi.org/10.1038/nature12297

164. Kanamori M, Nakatsukasa H, Ito M, Chikuma S, Yoshimura A (2018) Reprogramming of Th1 cells into regulatory T cells through rewiring of the metabolic status. Int Immunol 30(8):357373. https://doi.org/10.1093/intimm/dxy043

165. Basu S, Hubbard B, Shevach EM (2015) Foxp3-mediated inhibition of Akt inhibits Glut1 (glucose transporter 1) expression in human T regulatory cells. J Leukoc Biol 97(2):279-283. https:// doi.org/10.1189/jlb.2AB0514-273RR

166. Shrestha S, Yang K, Guy C, Vogel P, Neale G, Chi H (2015) Treg cells require the phosphatase PTEN to restrain TH1 and TFH cell responses. Nat Immunol 16(2):178-187. https://doi.org/10.1038/ ni.3076

167. Francisco LM, Salinas VH, Brown KE, Vanguri VK, Freeman GJ, Kuchroo VK, Sharpe AH (2009) PD-L1 regulates the development, maintenance, and function of induced regulatory $\mathrm{T}$ cells. J Exp Med 206(13):3015-3029. https://doi.org/10.1084/ jem.20090847

168. Patsoukis N, Brown J, Petkova V, Liu F, Li L, Boussiotis VA (2012) Selective effects of PD-1 on Akt and Ras pathways regulate molecular components of the cell cycle and inhibit $\mathrm{T}$ cell proliferation. Sci Signal 5(230):ra46. https://doi.org/10.1126/ scisignal.2002796

169. Gottschalk RA, Corse E, Allison JP (2010) TCR ligand density and affinity determine peripheral induction of Foxp3 in vivo. $\mathrm{J}$ Exp Med 207(8):1701-1711. https://doi.org/10.1084/jem.20091 999

170. Li MO, Rudensky AY (2016) T cell receptor signalling in the control of regulatory $\mathrm{T}$ cell differentiation and function. Nat Rev Immunol 16(4):220-233. https://doi.org/10.1038/nri.2016.26

171. O'Connor RS, Guo L, Ghassemi S, Snyder NW, Worth AJ, Weng L, Kam Y, Philipson B, Trefely S, Nunez-Cruz S, Blair IA, June CH, Milone MC (2018) The CPT1a inhibitor, etomoxir induces severe oxidative stress at commonly used concentrations. Sci Rep 8(1):6289. https://doi.org/10.1038/s41598-018-24676-6

172. Michalek RD, Gerriets VA, Nichols AG, Inoue M, Kazmin D, Chang CY, Dwyer MA, Nelson ER, Pollizzi KN, Ilkayeva O, Giguere V, Zuercher WJ, Powell JD, Shinohara ML, McDonnell 
DP, Rathmell JC (2011) Estrogen-related receptor- $\alpha$ is a metabolic regulator of effector T-cell activation and differentiation. Proc Natl Acad Sci U S A 108(45):18348-18353. https://doi.org/ 10.1073/pnas. 1108856108

173. Dang EV, Barbi J, Yang HY, Jinasena D, Yu H, Zheng Y, Bordman Z, Fu J, Kim Y, Yen HR, Luo W, Zeller K, Shimoda L, Topalian SL, Semenza GL, Dang CV, Pardoll DM, Pan F (2011) Control of T(H)17/T(reg) balance by hypoxia-inducible factor 1 . Cell 146(5):772-784. https://doi.org/10.1016/j.cell.2011.07.033

174. Feldhoff LM, Rueda CM, Moreno-Fernandez ME, Sauer J, Jackson CM, Chougnet CA, Rupp J (2017) IL-1 $\beta$ induced HIF-1 $\alpha$ inhibits the differentiation of human FOXP3(+) T cells. Sci Rep 7(1):465. https://doi.org/10.1038/s41598-017-00508-x

175. Clever D, Roychoudhuri R, Constantinides MG, Askenase MH, Sukumar M, Klebanoff CA, Eil RL, Hickman HD, Yu Z, Pan JH, Palmer DC, Phan AT, Goulding J, Gattinoni L, Goldrath AW, Belkaid Y, Restifo NP (2016) Oxygen sensing by T cells establishes an immunologically tolerant metastatic niche. Cell 166(5):1117-1131.e1114. https://doi.org/10.1016/j.cell.2016.07. 032

176. Lee JH, Elly C, Park Y, Liu YC (2015) E3 ubiquitin ligase VHL regulates hypoxia-inducible factor- $1 \alpha$ to maintain regulatory $\mathrm{T}$ Cell stability and suppressive capacity. Immunity 42(6):10621074. https://doi.org/10.1016/j.immuni.2015.05.016

177. Overacre-Delgoffe AE, Chikina M, Dadey RE, Yano H, Brunazzi EA, Shayan G, Horne W, Moskovitz JM, Kolls JK, Sander C, Shuai Y, Normolle DP, Kirkwood JM, Ferris RL, Delgoffe GM, Bruno TC, Workman CJ, Vignali DAA (2017) Interferon- $\gamma$ drives $\mathrm{T}(\mathrm{reg})$ fragility to promote anti-tumor immunity. Cell 169(6):1130-1141.e1111. https://doi.org/10.1016/j.cell.2017. 05.005

178. He N, Fan W, Henriquez B, Yu RT, Atkins AR, Liddle C, Zheng Y, Downes M, Evans RM (2017) Metabolic control of regulatory T cell (Treg) survival and function by Lkb1. Proc Natl Acad Sci U S A 114(47):12542-12547. https://doi.org/10.1073/pnas. 1715363114

179. Rotin D, Robinson B, Tannock IF (1986) Influence of hypoxia and an acidic environment on the metabolism and viability of cultured cells: potential implications for cell death in tumors. Cancer Res 46(6):2821-2826

180. Spill F, Reynolds DS, Kamm RD, Zaman MH (2016) Impact of the physical microenvironment on tumor progression and metastasis. Curr Opin Biotechnol 40:41-48. https://doi.org/10.1016/j. copbio.2016.02.007

181. Chaudhuri O, Koshy ST, Branco da Cunha C, Shin JW, Verbeke CS, Allison KH, Mooney DJ (2014) Extracellular matrix stiffness and composition jointly regulate the induction of malignant phenotypes in mammary epithelium. Nat Mater 13(10):970-978. https://doi.org/10.1038/nmat4009

182. Bollyky PL, Falk BA, Wu RP, Buckner JH, Wight TN, Nepom GT (2009) Intact extracellular matrix and the maintenance of immune tolerance: high molecular weight hyaluronan promotes persistence of induced CD4+CD25+ regulatory T cells. J Leukoc Biol 86(3):567-572. https://doi.org/10.1189/jlb.0109001

183. Lim AR, Rathmell WK, Rathmell JC (2020) The tumor microenvironment as a metabolic barrier to effector T cells and immunotherapy. Elife. https://doi.org/10.7554/eLife.55185

184. Schurich A, Magalhaes I, Mattsson J (2019) Metabolic regulation of CAR T cell function by the hypoxic microenvironment in solid tumors. Immunotherapy 11(4):335-345. https://doi.org/10.2217/ imt-2018-0141

185. Yadav UP, Singh T, Kumar P, Sharma P, Kaur H, Sharma S, Singh S, Kumar S, Mehta K (2020) Metabolic adaptations in cancer stem cells. Front Oncol 10:1010. https://doi.org/10.3389/ fonc. 2020.01010

186. Wang Y-A, Li X-L, Mo Y-Z, Fan C-M, Tang L, Xiong F, Guo C, Xiang B, Zhou M, Ma J, Huang X, Wu X, Li Y, Li G-Y, Zeng Z-Y, Xiong W (2018) Effects of tumor metabolic microenvironment on regulatory T cells. Mol Cancer 17(1):168. https://doi. org/10.1186/s12943-018-0913-y

Publisher's Note Springer Nature remains neutral with regard to jurisdictional claims in published maps and institutional affiliations. 